\title{
Geologia e significado tectônico das rochas metavulcanossedimentares do Complexo Coxilha do Batovi, Cinturão Dom Feliciano (São Gabriel, RS)
}

\author{
Mauricio SALVI' \& Ruy Paulo PHILIPP2 \\ 1 Programa de Pós-Graduação em Geociências, Instituto de Geociências, Universidade Federal \\ do Rio Grande do Sul. Av. Bento Gonçalves 9.500, CEP 91501-970, Porto Alegre, RS, Brasil \\ (mauriciosalvi@yahoo.com.br). \\ 2 Centro de Estudos em Petrologia e Geoquímica, Instituto de Geociências, Universidade Federal do Rio \\ Grande do Sul (ruy.philipp@ufrgs.br).
}

\begin{abstract}
Resumo. O Complexo Coxilha do Batovi (CCB) é uma sequência metavulcanossedimentar de idade pré-cambriana exposto em uma janela estrutural ao sul da cidade de São Gabriel. Para entender a evolução estrutural do complexo foi realizado um estudo integrado de estratigrafia, sedimentologia, análise petrográfica, geologia estrutural e petrologia metamórfica. O CCB está situado no extremo sudoeste do limite do Terreno Taquarembó, sobre a Zona de Cisalhamento Ibaré de direção NW-SE. É composto por meta-arenitos quartzíticos e arcoseanos finos a médios e metapelitos, com mármores, rochas metavulcânicas, formações ferríferas bandadas e metagranitos subordinados. As rochas do CCB registram uma complexa trama estrutural, resultante de uma história de deformação progressiva associada a um metamorfismo orogênico de baixo grau, na fácies Xistos Verdes. A espessura original do pacote sedimentar está multiplicada pela ação de dobras isoclinais e pela transposição da xistosidade principal. Em porções menos deformadas observa-se estratificação plano-paralela, cruzada acanalada e cruzada planar de baixo ângulo. Os perfis colunares levantados sugerem uma sequência de sedimentos progradantes caracterizados por sedimentos siliciclásticos quartzosos e carbonáticos depositados provavelmente em um ambiente deltaico em uma bacia intracratônica ou de margem passiva. A deformação do complexo resulta de um encurtamento regional de direção NE-SW, cuja máxima atuação da deformação gerou a Zona de Cisalhamento Ibaré.

Palavras-chave. Neoproterozoico, Cinturão Dom Feliciano, Terreno Taquarembó, metamorfismo orogênico, estratigrafia, Zona de Cisalhamento Ibaré.
\end{abstract}

Abstract. GEOLOGY AND TECTONIC SIGNIFICANCE OF THE METAVULCANO-SEDIMENTARY ROCKS OF
THE COXILHA DO BATOVI COMPLEX, DOM FELICIANO BELT (SÃO GABRIEL, RS). The COxilha do Batovi
Complex (CCB) is a Precambrian metavolcano-sedimentary sequence, exposed in a structural
framework south of the town of São Gabriel. To understand the structural evolution of the
complex, an integrated study of stratigraphy, sedimentology, petrographic analysis, structural
geology and metamorphic petrology was carried out. The CCB is located at the southwestern
end of the Taquarembó Terrane boundary, over the NW-SE direction Ibaré Shear Zone. The CCB
is composed of fine to medium quartzitic and arkosean meta-sandstones and metapelites,
with a subordinate occurrence of marbles, metavolcanic rocks, banded iron formations and
metagranites. The rocks of the CCB record a complex structural fabric, resulting from a long
history of progressive deformation associated to a low grade orogenic metamorphism, of
greenschist facies conditions. The original thickness of the sedimentary package is multiplied by
theaction of isoclinal folds and by the crenulation and transposition of the main schistosity. In less
deformed portions, are preserved primary structures such as plane-parallel stratification, trough
cross-bedding, and low-angle planar cross-bedding. The measured and interpreted columnar
profiles suggest a prograding sequence, composed of a thick package of meta-sandstones that
grade to a rhythmic intercalation with metapelites superimposed by another thick package of
meta-sandstones. The CCB rocks represent quartzitic and carbonate siliciclastic sediments
likely deposited in a delta environment in an intracratonic or passive margin basin. The rocks of
the complex are deformed by the action of a regional shortening of NE-SW direction, associated
with the formation of foliations $\mathrm{S}_{1}$ and $\mathrm{S}_{2}$, whose maximum deformation performance generated
the Ibaré Shear Zone.

Keywords. Dom Feliciano Belt, Taquarembó Terrane, orogenic metamorphism, stratigraphy, sedimentology. 


\section{Introdução}

O entendimento tectono-metamórfica de um complexo metavulcanossedimentar requer a utilização de uma metodologia de pesquisa com enfoque interdisciplinar. Para o Complexo Coxilha do Batovi (CCB), foi realizado um estudo integrado de estratigrafia, geologia estrutural, análise petrográfica e petrologia metamórfica. O CCB é uma sequência metavulcanossedimentar précambriana metamorfisada e deformada durante o Ciclo Brasiliano, cuja dinâmica culminou na criação de uma complexa trama estrutural. A observação nos protólitos de estruturas e texturas reliquiares, bem como a relação entre as condições metamórficas (pressão litostática e temperatura) e as fases de deformação observadas são as premissas para aprimorar o entendimento da evolução das unidades na área estudada.

O Escudo Sul-Rio-Grandense (ESRG) é composto por duas unidades geotectônicas definidas por características estruturais, geofísicas, petrológicas, geoquímicas e geocronológicas distintas. O Cráton Rio de La Plata é a unidade mais antiga e está representada pelo Terreno Taquarembó, localizado no extremo sudoeste do ESRG. O Cinturão Dom Feliciano (CDF) é representado no RS pelos terrenos São Gabriel e Tijucas e pelo Batólito de Pelotas, e envolve esta unidade mais antiga ao norte e ao leste. A construção do ESRG inicialmente envolveu o fechamento do oceano Charrua durante a Orogênese São Gabriel (900-680 Ma) e, posteriormente, o fechamento do oceano Adamastor e a colisão entre os crátons Rio de la Plata e Kalahari durante a Orogênese Dom Feliciano (650-550 Ma), ocorrida no final da evolução do Ciclo Orogênico Brasiliano (Babinski et al., 1996; Chemale Jr., 2000; Hartmann et al., 2007; Saalmann et al., 2010; Philipp et al., 2016a). As rochas do embasamento foram intensamente deformadas e metamorfizadas ao final do processo colisional, formando intercalações tectônicas entre segmentos de níveis infra e supracrustais. Esses fatos explicam a dificuldade em separar as unidades e em compreender a sequência detalhada de eventos ocorridos durante o Ciclo Orogênico Brasiliano.

O CCB é constituído por uma intercalação de rochas metavulcanossedimentares intrudidas por rochas metagraníticas de idades précambriana, localizado no extremo noroeste da Zona de Cisalhamento Ibaré (ZCI) de direção NW-SE. A exposição do complexo ocorre como uma janela estrutural, envolta por formações sedimentares paleozoicas da Bacia do Paraná. o complexo é composto por metapsamitos quartzíticos à sub-arcoseanos e calcíferos, metapelitos e mármores, com ocorrência subordinada de rochas metavulcânicas, formações ferríferas bandadas (fácies hematita e fácies turmalina) e metagranitóides. As rochas do complexo estão polideformadas e registram um metamorfismo orogênico de baixo a médio grau, entre a Fácies Xisto Verde e Anfibolito.

O principal objetivo deste trabalho é a caracterização geológica e estrutural do CCB através da apresentação de dados estratigráficos, estruturais, petrográficos e micro-estruturais. Serão abordadas questões como o tipo de bacia que originou os metassedimentos do CCB, os paleoambientes deposicionais, culminando com uma discussão sobre o seu posicionamento geotectônico e relações com rochas adjacentes.

\section{2 Área, materiais e métodos}

\subsection{Contexto geológico regional}

A região estudada faz parte do Setor Meridional da Província Mantiqueira (Almeida et al., 1981), interpretada como o resultado de diversas colagens orogênicas diacrônicas de blocos cratônicos e cinturões orogênicos durante - Neoproterozoico-Cambriano, formando o setor sudoeste do paleocontinente Gondwana (Chemale Jr., 2000; Silva et al., 2005; Hartmann et al., 2007).

O Escudo Sul-Rio-Grandense (ESRG) é o resultado dos processos de geração e deformação de crosta continental e oceânica, cujas maiores contribuições são registradas em dois principais ciclos orogênicos, o ciclo Transamazônico (2.2$2.0 \mathrm{Ga}$ ) e o ciclo Brasiliano (900-540 Ma). O Cráton Rio de La Plata (CRLP) está representado no RS pelo Terreno Taquarembó, um fragmento 
de idade paleoproterozoica situado no extremo sudoeste do ESRG. O Cinturão Dom Feliciano (CDF) constitui uma faixa orogênica de idade Neoproterozoica direcionada segundo NE-SW, construída na porção oriental do CRLP durante o Ciclo Brasiliano e que se estende para o estado de Santa Catarina e para o Uruguai (Fig. 1). As unidades do CDF estão representadas pelos terrenos São Gabriel (TSG), Tijucas (TJ) e Punta del Este, e pelos batólitos Florianópolis, Pelotas e Aiguá (Philipp et al., 2016a). Os contatos entre estas unidades estão definidos por zonas de cisalhamento dúcteis de expressão regional de direções N20-40 $\mathrm{E}, \mathrm{N} 60-80^{\circ} \mathrm{E}$ e N30-40 $\mathrm{W}$.

O Terreno Taquarembó é composto por rochas de idade paleoproterozoica, interpretadas como um fragmento da Microplaca ou Terreno Nico Perez, unidade intensamente deformada durante o neoproterozoico e que envolve o núcleo continental preservado do Cráton Rio de La Plata (CRLP) (Oyhantçabal et al., 2011; Rapela et al., 2011; Philipp et al., 2016a). A continuidade destas áreas do CDF é interpretada como a zona de sutura entre os crátons Rio de La Plata (CRLP) e Kalahari (Fragoso-Cesar, 1980, 1991; Soliani Jr., 1986; Fernandes et al., 1992). Fragmentos do Terreno Nico Perez no ESRG ficaram preservados como complexos ortognáissicos de idade paleoproterozoica (Complexo Granulítico Santa Maria Chico, complexos Encantadas, Arroio dos Ratos e Vigia).

O Terreno São Gabriel contém associações vulcânicas e plutônicas de caráter juvenil intercaladas com ofiolitos, representando a abertura e o fechamento do oceano Charrua, com a criação de um arco ilhas oceânico (Arco Passinho) e um arco de margem continental (Arco São Gabriel), acrescionados na borda ocidental do CDF durante as orogêneses Passinho (900$850 \mathrm{Ma}$ ) e São Gabriel (760-680 Ma) (Chemale Jr., 2000; Hartmann et al., 2007; Saalmann et al., 2005, 2010; Philipp et al., 2016a) (Fig. 2).

A evolução final do cinturão está caracterizada pela orogênese Dom Feliciano, associada com um metamorfismo orogênico associado à colisão dos crátons Rio de La Plata e Kalahari, entre 650 e 620 Ma (Chemale Jr., 2011; Philipp et al. 2016b). Após o pico do metamorfismo colisional, seguiu-se uma intensa granitogênese de caráter pós-colisional, entre 600 e 550 Ma (Bitencourt \& Nardi, 2000; Philipp et al., 2000; Philipp \& Machado, 2005).

\subsection{Relações estratigráficas do Complexo Coxilha do Batovi}

O CCB está situado na porção sul do município de São Gabriel, a 55 quilômetros da zona urbana, no Distrito do Batovi e apresenta uma área mapeada de aproximadamente $18 \mathrm{Km}^{2}$. Está disposto sobre a Zona de Cisalhamento Ibaré no limite entre os terrenos Taquarembó e São Gabriel e está parcialmente encoberto ao leste e ao norte pelas rochas sedimentares do Grupo Itararé e da Formação Rio Bonito (Grupo Guatá) da Bacia do Paraná (Fig. 2 e 3).

As sequências metavulcanossedimentares do ESRG foram estudadas inicialmente na década de 60 (Goñi et al., 1962; Jost \& Villwock, 1966) quando foram agrupadas para constituir a Formação Vacacaí. Posteriormente, com a evolução da cartografia geológica e da estratigrafia, foram desmembradas em complexos com designações geográficas regionais (Palma, Passo do Ivo, Bossoroca, Cambaizinho, Passo Feio, Arroio Marmeleiro, Coxilha do Batovi, entre outros). Estes complexos foram estudados através da integração de dados petrográficos e geoquímicos (Garcia \& Hartmann, 1981; Chemale Jr., 1982; Bitencourt, 1983; Naumann, 1985; Zarpelon, 1986; Remus, 1990; Wildner, 1990; Schmitt, 1995; dentre outros).

A região de Coxilha do Batovi foi muito pouco estudada, sendo objeto de levantamentos de enfoque geológico e estratigráfico regional. 0 primeiro relato geológico foi feito por Leinz (1946) que discorreu a respeito dos calcários, incluindo essas rochas na Série Porongos de Carvalho (1932). Szubert \& Presotto (1974) destacaram a presença de mármores cinza-escuros a pretos com níveis brancos subordinados na localidade do Batovi. Nos levantamentos da Folha São Gabriel (1:100.000) e no mapa geológico do Rio Grande do Sul, Issler et al. (1972) e Carraro et al. (1974), posicionaram as rochas da "Coxilia" do Batovi dentro do Grupo Cambaí. Silva (1983) reconheceu o predomínio de metagrauvacas com raras lentes de calcário na porção norte 


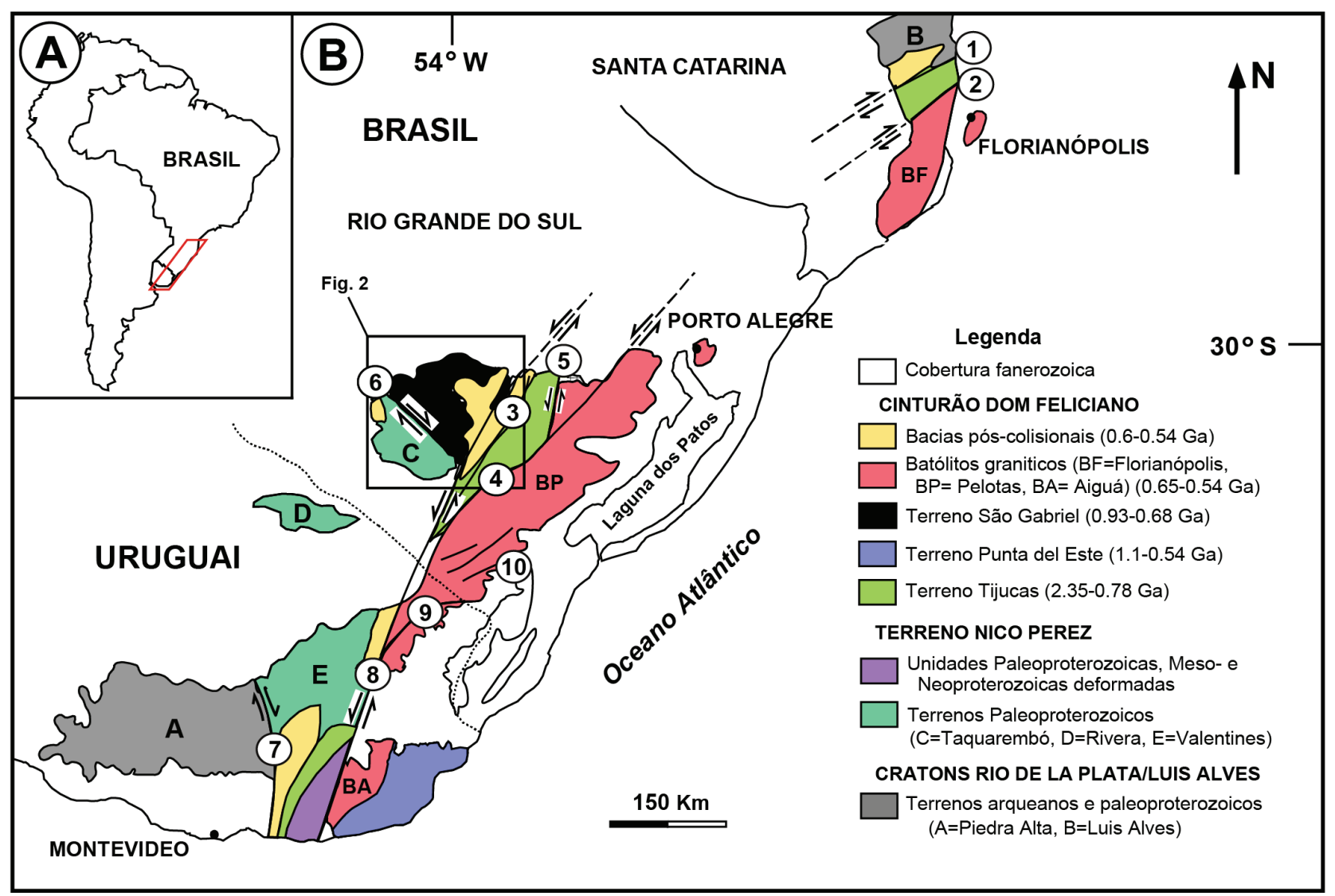

Figura 1. Localização da área estudada e contexto geotectônico. A) Localização na América do Sul; B) Principais unidades geotectônicas do sul do Brasil e UruguaiUruguai. Retirado de Philipp et al. (2016a). Principais Zonas de cisalhamento: 1- Itajaí-Perimbó, 2- Major Gercino, 3- Santana da Boa Vista, 4- Dorsal de Canguçu, 5- Passo do Marinheiro, 6- Ibaré, 7- Sarandi Del Yí, 8- Sierra Ballena, 9- Cerro Amaro, 10- Arroio Grande. Localização da área de estudo do mapa da figura 2 no quadrado preto.. vermelho.

Figure 1. Location of the studied area. A) Location at South America; B) Main geotectonic units of southern Brazil and Uruguay. Adapted from Philipp et al. (2016a). Main shear zones: 1- Itajaí-Perimbó, 2- Major Gercino, 3- Santana da Boa Vista, 4- Dorsal de Canguçu, 5- Passo do Marinheiro, 6- Ibaré, 7- Sarandi Del Yí, 8- Sierra Ballena, 9- Cerro Amaro, 10 Arroio Grande. Location of the map of the figure 2 study area in the red black square.

do complexo e metapelitos com intercalação de metacalcários na porção sul. Esse autor associou as sequências metavulcanossedimentares descontinuas de baixo grau do Batovi, Ibaré e Marmeleiro como pertencentes a uma unidade do tipo "Greenstone Belt", atribuindo uma idade entre o Arqueano Superior e o Proterozoico Inferior. O mapeamento geológico executado pelo Instituto de Geociências da Universidade Federal do Rio Grande do Sul (UFRGS, 1986) propôs o nome Complexo Metamórfico Batovi, reconhecendo uma porção constituída por granitos deformados, gnaisses quartzo-feldspáticos, "BIF's" e metabasitos metamorfizados em condições de fácies epidoto-anfibolito, e uma porção composta por metapelitos, metapsamitos, mármores e metavulcânicas, afetadas por um grau baixo, na fácies xisto-verde.

Nos levantamentos de semi-detalhe desenvolvidos por Schmitt (1995), o CCB é composto por metapsamitos arcoseanos, quartzíticos e calcíferos, metapelitos, mármores (grafita mármore calcítico, mármore dolomítico silicoso e brechas dolomíticas), metabasaltos espilíticos e rochas metavulcano-clásticas, formações ferríferas bandadas das fácies sulfeto e óxidos metamorfisadas e metagranitoides. Laux et al. (2010b) apresentaram para uma rocha metavulcano-clástica uma idade U-Pb zircão (LA-ICP-MS) de $1.764 \pm 33 \mathrm{Ma}$, interpretada como a idade da deposição da sequência vulcano-sedimentar. Os autores salientam que as rochas metavulcânicas do CCB apresentam características geoquímicas compatíveis com a de basaltos toleíticos de arcos de ilha com assinatura E-MORB (Laux et al., 2010b7).

Esse trabalho avalia a possibilidade de correlação do CCB com os complexos 


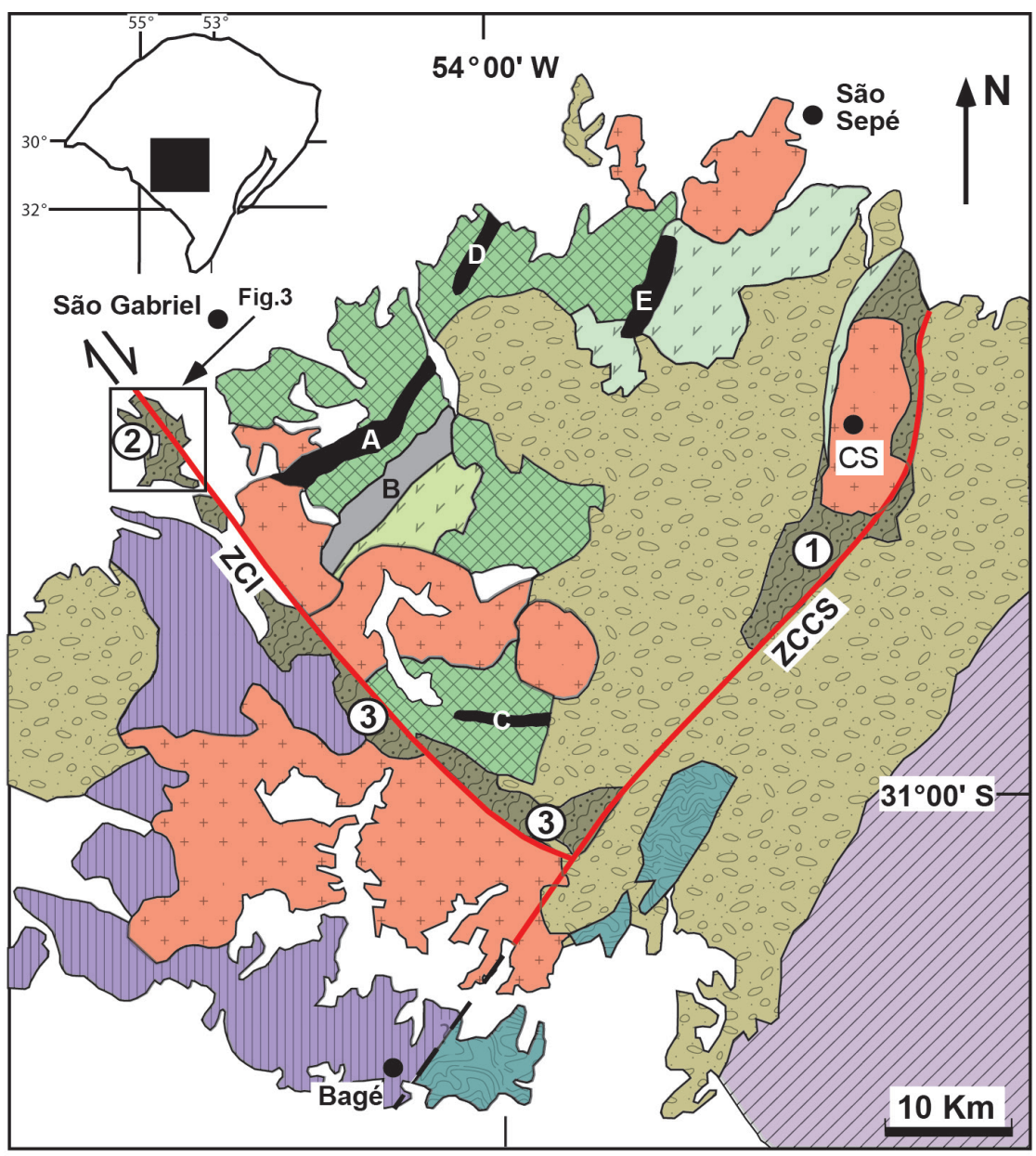

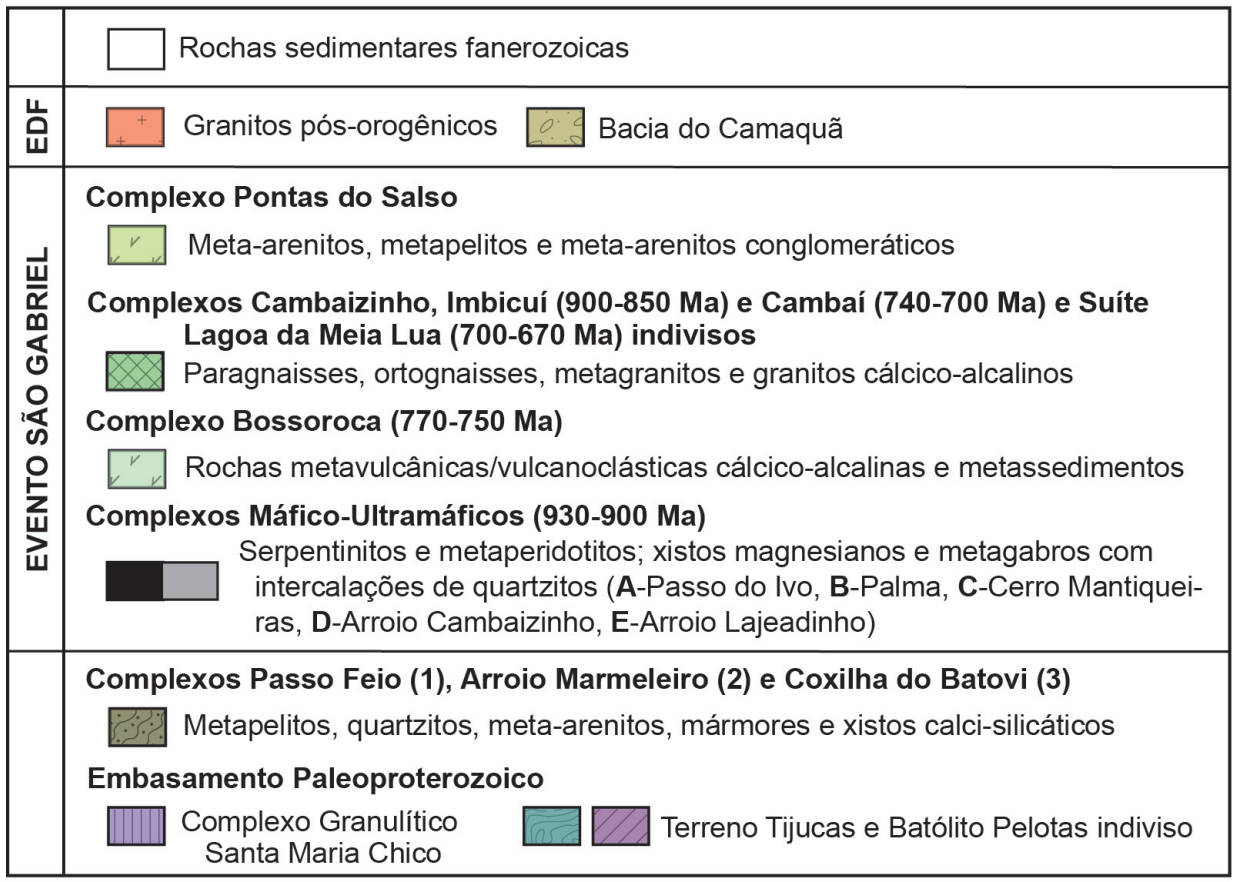

Figura 2. Mapa da porção oeste do Escudo Sul-Rio-Grandense destacando os terrenos São Gabriel e Taquarembó. A área de estudo está indicada pelo quadrado em preto. Modificado de Vedana et al. (2017). Zonas de cisalhamento: ZCl: Ibaré e ZCCS: Caçapava do Sul. CS = cidade de Caçapava do Sul. Localização da área de estudo e do mapa geológico da figura 3 no quadrado preto.

Figure 2. Map of the western portion of the Sul-Rio-Grandense Shield highlighting the São Gabriel and Taquarembó terranes. The study area is indicated by the black square. Modified from Vedana et al. (2017). Location of the study area and of the geological map of the figure 3 in the black square. 
metavulcanossedimentares Passo Feio e Marmeleiro. O primeiro ocorre na região de Caçapava do Sul, com direção $\mathrm{N} 20^{\circ} \mathrm{E}$, se estende desde a sutura de Caçapava descendo para o sul e infletindo na Zona de Cisalhamento Ibaré para a direção $N 45^{\circ} \mathrm{W}$, quando então passa a ser denominado Complexo Arroio Marmeleiro. As características composicionais destas unidades sugerem que as mesmas representam os produtos de uma bacia sedimentar formada em um ambiente de margem passiva, do então denominado Oceano Charrua de idade Toniana (Philipp et al., 2016a; Arena et al., 2016). Com o fechamento do oceano Charrua e a colisão entre os arcos magmáticos gerados contra o Terreno Nico Perez e o Cráton Rio de La Plata, durante a formação do paleocontinente Gondwana (Neoproterozoico-Cambriano), a antiga bacia de margem passiva foi deformada e metamorfisada.

\subsection{Materiais e métodos}

A metodologia utilizada envolveu o mapeamentogeológicoemescala 1:50.000, coleta de amostras de rocha e dados estruturais, análise petrográfica, construção de seções geológicas e perfis colunares estratigráficos e croquis de detalhe de afloramentos representativos do complexo. Foram efetuados dois levantamentos de campo no total de 9 dias posteriores à revisão bibliográfica e análise de imagens e mapas. Nos trabalhos de campo foram descritos os afloramentos em cortes de estradas, leitos de drenagem e em antigas pedreiras de brita, com levantamento das estruturas internas, contatos litológicos e perfis de amostragem de rocha para confecção de lâminas delgadas. No total foram descritos 38 pontos com a coleta de amostras e 268 medidas estruturais. Os mapas, lâminas delgadas e dados levantados pelo trabalho de Schmitt (1995) também foram utilizados, além de fotos aéreas e imagens do Google Earth. Os pontos descritos foram localizados mediante uso do GPS da marca Garmin $\AA$ modelo GPS map 60CSx em coordenadas UTM e Datum SAD69 e da carta topográfica 1:50.000 do Serviço Geográfico do Exército, folha Suspiro SH.21-Z-B-VI-1. Foram confeccionadas 18 novas lâminas delgadas para análise petrográfica em luz transmitida.
As seções delgadas foram confeccionadas nos Laboratório de Preparação de Amostras do Centro de Pesquisas em Petrologia e Geoquímica (CPGq) do Instituto de Geociências da UFRGS.

\section{Resultados}

\subsection{Geologia do Complexo Coxilha do Batovi}

O Complexo Coxilha do Batovi (CCB) constitui um corpo alongado segundo a direção $\mathrm{N} 45^{\circ} \mathrm{W}$, apresentando entre 10 e $8 \mathrm{~km}$ de extensão, e largura entre de 1 a 3 km; está situado no extremo noroeste da Zona de Cisalhamento Ibaré (ZCI). No seu limite norte e leste é recoberto pelas rochas sedimentares da Formação Rio Bonito, e em seu extremo noroeste, o contato com esta unidade é definido por uma falha normal. Na sua porção NW é recoberto pelas rochas sedimentares; do Grupo Itararé. O contato com o Complexo Granulítico Santa Maria Chico, a sudoeste, é definido por falha transcorrente com movimento lateral esquerdo, que difere do padrão da ZCl, que tem cinemática principal dextral.

As rochas do CCB incluem essencialmente metassedimentos, com ocorrência subordinada de rochas metavulcânicas e formações ferríferas bandadas. Entre os metassedimentos, os metaarenitos são o tipo mais comum, ocorrendo ainda intercalações subordinadas de mármores e metapelitos. Afloram em cristas alongadas com centenas de metros de comprimento e algumas dezenas de largura, como lajeados nos leitos das drenagens, em antigas pedreiras e também em cortes de estrada. De forma geral, predominam os meta-arenitos na porção norte e central do complexo, com a intercalação com metapelitos gradativamente aumentando para o sul.

Os meta-arenitos constituem o pacote litológico mais espesso do complexo, com espessuras que podem atingir várias dezenas de metros. Estão intercalados com raros níveis de metapelitos e lentes de mármores. Possuem cor bege ou esbranquiçada, com tom esverdeado a cinzento nos níveis com mais clorita e/ou muscovita e alaranjado quando oxidado. Podem ser distintos três litotipos. Os metapsamitos quartzíticos são os mais abundantes, apresentam xistosidade incipiente, com espaçamento 


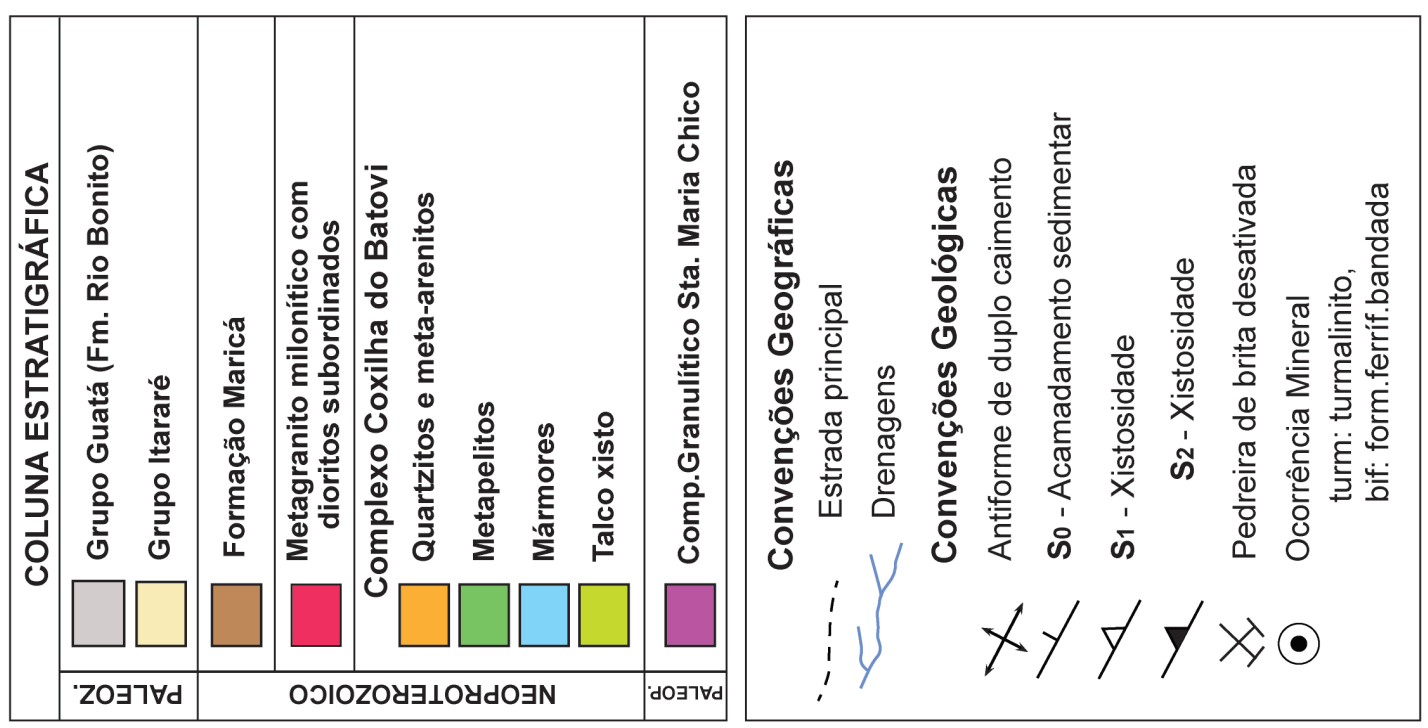

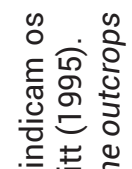

$\therefore \stackrel{\square}{5}$

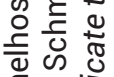

है

$\stackrel{2}{0} \div \frac{1}{2}$

क 듕 융

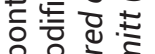

क ए

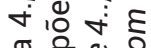

政 $\frac{0}{\pi}$

可

증융 \&

क $\frac{\pi}{0} .5$

등 용

음

बुं

\& एक

워․

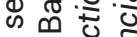

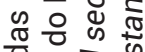

. $\frac{\pi}{\pi}$

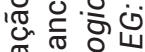

需要

읍

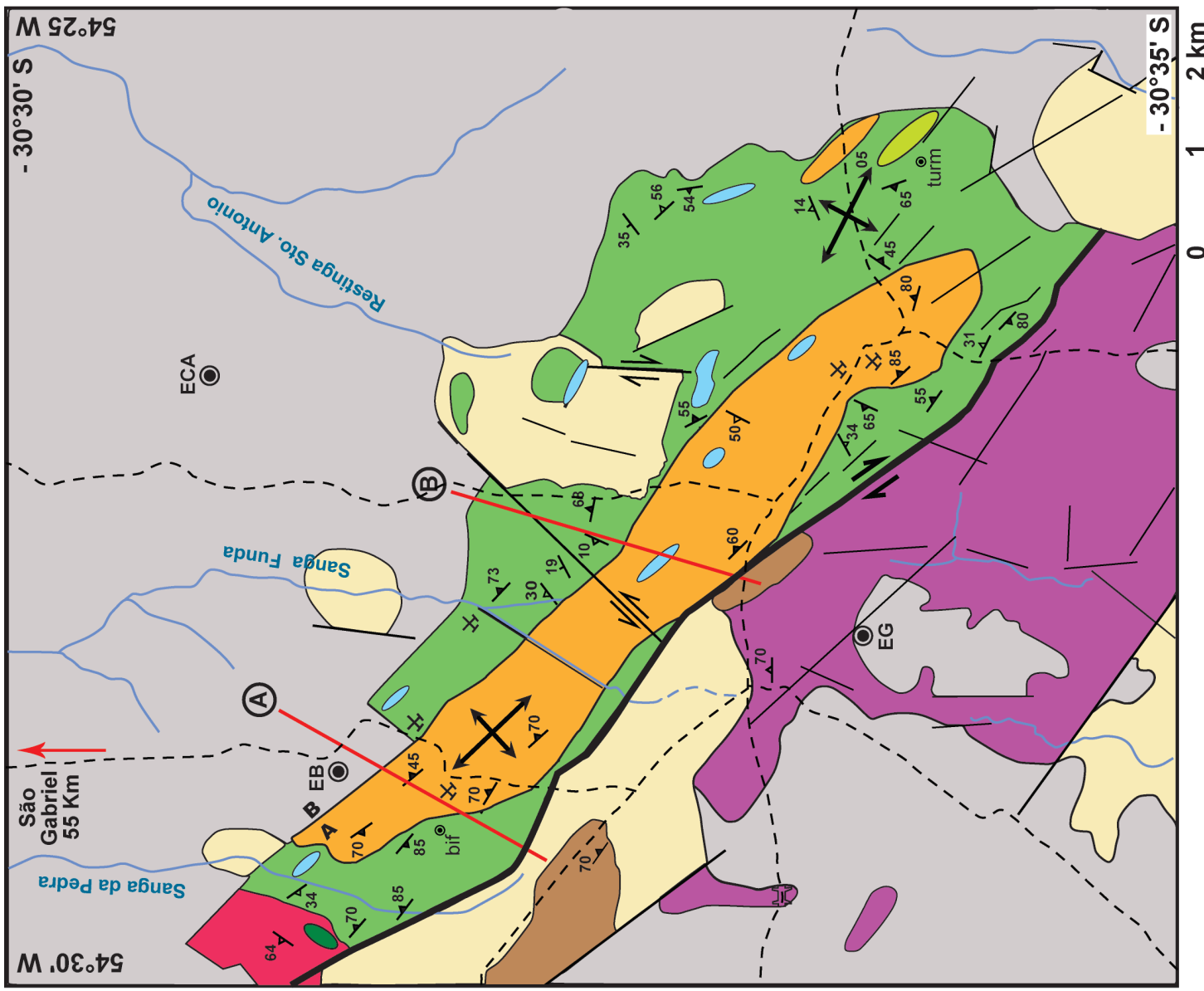

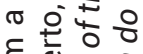

结这

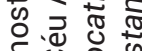

는

응 용

《. 중 क

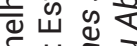
है 出 का is 至 $\frac{\pi}{0} \frac{0}{0} \frac{\pi}{0}$ 为需飞新 家웜 윰 응 응 응 응 준 $\frac{\pi}{5}$

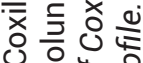
증 흥 흫 2.0 응 항 는 है 증 $\frac{\pi}{4}$ ㄴㅇㅇ 을 ठ․ㅇ है 잉 त् है o 주응 i⿱ $)$ i ब ता है थ है

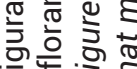

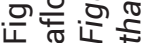


milimétrico definido por níveis muito finos ricos em muscovita e/ou clorita. Observa-se nos termos pouco deformados a presença de estruturas primárias como acamadamento plano-paralelo, estratificação cruzada de baixo ângulo e camadas microgradadas. Nos termos mais deformados são desenvolvidas diferentes estruturas de comportamento dúctil como boudins e dobras, dúctil/rúpteis como "gash veins", e rúpteis como falhas e fraturas. A textura principal é granoblástica equigranular interlobada fina, ocorrendo também textura blastopsamítica, caracterizada pela presença de porfiroclastos de areia média com formas subarredondadas envoltos por matriz fina recristalizada. Nos níveis ricos em micas a textura é lepidoblástica fina e está definida pela orientação de muscovita e clorita.

Os meta-arcóseos são encontrados como lentes de até $2 \mathrm{~m}$ de espessura, com poucas e alteradas exposições principalmente em cortes de estrada; apresentam textura blastopsamítica média à grossa composta por níveis ricos em porfiroclastos de feldspato e quartzo alternados com níveis ricos em minerais micáceos e quartzo recristalizado; exibem foliação protomilonítica, caracterizada pelo estiramento e pela formação de caudas recristalizadas em porfiroclastos de quartzo e por porfiroclastos do tipo mica fish; ocorrem ainda de maneira restrita no extremo norte do complexo, em contato com os mármores e com as formações ferríferas.

Os metapelitos tem distribuição subordinada, composição a base de muscovita e estão comumente alterados; formam pacotes com espessuras que variam de 0,5 a $4 \mathrm{~m}$, e estão intercalados entre os meta-arenitos e os mármores dolomíticos. Comumente exibem cor bege nos níveis siltosos e cinza-azulado a preto nos níveis ricos em turmalina e grafita. Quando alterados possuem cor vermelho-alaranjada e verde-clara para os níveis ricos em clorita. As melhores exposições ocorrem em cortes de antigas pedreiras.

Os mármores foram descritos inicialmente por Leinz (1946) e Szubert \& Presotto (1974), que relatam a ocorrência de grafita mármore calcítico de cor cinza escura a preta, intercalado com bancos de calcáreos claros de granulação muito fina. Formam lentes de até $100 \mathrm{~m}$ de comprimento por até $60 \mathrm{~m}$ de espessura e são encontrados em pequenas pedreiras abandonadas. Os mármores dolomíticos silicosos descritos por Schmitt (1995) ocorrem na forma de lentes com até $2 \mathrm{~m}$ de espessura, intercalados entre os metaarenitos e metapelitos. Nos domínios menos deformados está preservado o acamadamento sedimentar (SO), marcado pela intercalação de calcita micrítica e grafita. Schmitt et al. (1993) descrevem essas rochas como geradas a partir da atividade orgânica de colônias de Cyanobacteria, caracterizando um "lamito criptomicrobial", que sofreu intensa diagênese, dissolvendo as esteiras de microrganismos, restando apenas traços curtos arrebentados. Ainda são encontradas brechas dolomíticas formando diques ou bolsões que afloram paralelas a $\mathrm{ZCl}$, cuja principal exposição encontra-se em uma antiga pedreira localizada no extremo noroeste do complexo. As brechas dolomíticas apresentam cor branca, matriz microcristalina de quartzo, calcita e dolomita, com litoclastos de mármore branco e grafita mármore.

As rochas metavulcânicas são encontradas no extremo norte do complexo, muito fraturadas, de cor verde escura variando de termos afaníticos à amigdaloidais. Foram descritas por Schmitt (1995) como metabasaltos e espilitos amigdaloidais, com prováveis estruturas do tipo pillow lavas metamorfizados entre às fácies prehnita-pumpelleyíta e cloritapumpelleyíta. Não apresentam deformação de caráter dúctil e não é possível observar seus contatos com as demais unidades. Na Sanga da Pedra, situada no extremo noroeste do CCB, foi observado um clorita-actinolita xisto de cor verde escura e textura netamoblástica fina. Apresentando feições de comportamento dúctil como dobras, tem contatos concordantes com os mármores dolomíticos ao norte, e ao sul com os metapsamitos quartzíticos, e contato por falha transcorrente com o Complexo Granulítico Santa Maria Chico (CGSMC) a oeste. Exibe injeções concordantes de metaleucogranitos equigranulares, desenvolvendo boudins e estruturas tipo pinch e swell.

A formação ferrífera bandeada está caracterizada pela intercalação de níveis ricos 
em minerais opacos (perfazem até 40\% da rocha) e níveis quartzíticos. Em campo, formam lentes de até $2 \mathrm{~m}$ de espessura por até $10 \mathrm{~m}$ de comprimento, apresentam cor preta, com níveis alaranjados quando alterada.

Os metaleucogranitos apresentam textura equigranular média à fina e formam lentes de até $2 \mathrm{~m}$ de espessura por $10 \mathrm{~m}$ de comprimento seguindo a direção NW-SE. Ocorrem ainda em contato com o CGSMC. Essas rochas intrudem as formações ferríferas bandadas gerando um aspecto gnáissico pela intercalação das bandas rosáceas do metagranito, com as bandas máficas. Forma estruturas do tipo pinch, swell e boudin. Foram classificadas como monzodioritos a monzogranitos (Schmitt, 1995).

A partir da análise dos dados de campo é possível interpretar a exposição do complexo como uma janela estrutural, aflorando rochas pertencentes ao embasamento do Escudo Sul-rio-grandense, envoltas por formações sedimentares da Bacia do Paraná. Fica evidente também, a forma alongada segundo a direção NW-SE para as rochas do CCB, assim como para as do Complexo Granulítico Santa Maria Chico, com as quais faz contato (Fig. 3). As drenagens que cortam a área estão dispostas principalmente na direção norte-sul, encaixadas em um padrão de fraturamento mais jovem, provavelmente do Fanerozoico.

A localização das seções geológicas levantadas em campo está representada no mapa da figura 3 como linhas vermelhas. As seções e os perfis colunares levantados estão dispostos de forma perpendicular à estruturação geral do complexo, a fim de ilustrar o comportamento das principais estruturas verificadas, tais como foliações, dobras, entre outras. As seções geológicas A e B da figura 4 mostram o padrão estrutural do complexo, evidenciado pelo intenso dobramento da foliação principal $\left(S_{1}\right)$, com dobras $F_{2}$ fechadas a isoclinais, falhas inversas e intrusão de veios de quartzo tardios.

O perfil colunar levantado a partir dos afloramentos indicados no mapa da figura 3 como pontos vermelhos, mostra na base, um espesso pacote de meta-arenitos que passa para uma intercalação rítmica com metapelitos. Essa intercalação tem sua frequência aumentada até formar um espesso pacote de metapelitos com uma lente de mármore, que por sua vez, é sobreposto por outro pacote espesso de meta-arenito. O padrão de intercalação dos metassedimentos é mostrado de forma simplificada no perfil colunar da figura 5. A feição principal de relevo do denominado Cerro e/ou Coxilha do Batovi é definida por uma crista principal composta pela intercalação de quartzitos e meta-arcóseos (Fig. 6A).

\subsection{Geologia estrutural}

O registro da superposição de fases deformacionais, a grande quantidade de fraturas e falhas, a formação de protomilonitos (Fig. 6D), e o baixo grau metamórfico observados no CCB permitem inferir que a deformação do complexo tenha ocorrido em níveis crustais intermediários a pouco profundos. Observa-se a preservação de estruturas em afloramentos que registram diferentes estágios da evolução progressiva das fases deformacionais. O CCB apresenta uma complexa trama estrutural, resultante provavelmente de uma longa história de deformação progressiva. Em porções menos deformadas são identificadas estruturas primárias nos protólitos sedimentares como estratificação plano-paralela, cruzada acanalada e cruzada planar de baixo ângulo (Fig. 6B, E e F).

A observação do mapa da figura 3 mostra que a xistosidade $S_{1}$ apresenta orientação principal segundo a direção N50-60 $\mathrm{W}$, com mergulhos alternados para NE e SW. A transposição do acamadamento primário durante a geração da foliação $S_{1}$ é responsável pela intercalação das lentes de mármores, que estão concentradas na porção norte e central do complexo. O dobramento da foliação $S_{1}$ ocasiona a formação de uma clivagem de crenulação $\left(S_{2}\right)$, preservando dobras $F_{2^{\prime}}$ que são reconhecidas em campo como antiformes regionais, mostrando eixos orientados segundo a direção NW-SE como indicado no mapa da figura 3.

Foram identificadas três fases de deformação denominadas $D_{1}, D_{2}$ e $D_{3}$. A fase $D_{1}$ apresenta caráter dúctil e está caracterizada pela transposição do acamamento sedimentar e geração da clivagem ardosiana e/ou xistosidade 

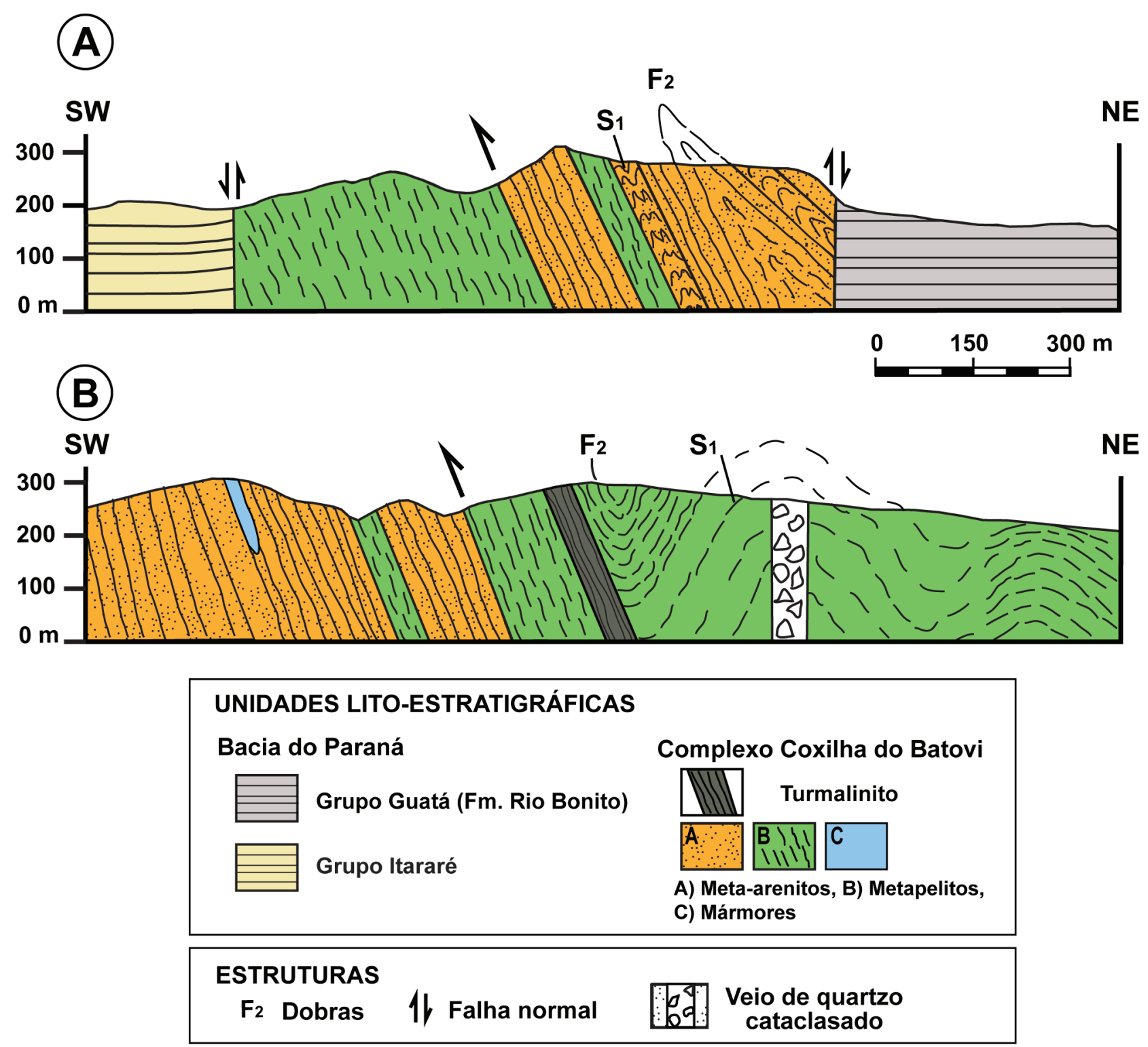

Figura 4. Seções geológicas A e B indicadas no mapa geológico da figura 3, mostrando as principais estruturas do Complexo Coxilha do Batovi.

Figure 4. Geological sections A and B indicated in the geological map of figure 3, showing the main structures of the Coxilha do Batovi Complex.

principal da área $\left(\mathrm{S}_{1}\right)$. A segunda fase produz 0 dobramento e transposição local da foliação $S_{1}$, gerando uma clivagem de crenulação $S_{2^{\prime}}$ como se verifica na figura $7 A-B$, e também estruturas como boudins, pinch e swell e diversos tipos de dobras $F_{2^{\prime}}$ simétricas a assimétricas, fechadas a isoclinais, com eixos direcionados segundo a direção NW-SE (Fig. 7C). A terceira fase produziu dobras tardias, originando uma clivagem de fratura $\left(S_{3}\right)$ associada, caracterizada por superfícies planas e retilíneas, em geral com espaçamentos entre 10 e $40 \mathrm{~cm}$, (figuras 8A,B,C). As dobras $F_{3}$ são abertas a suaves e apresentam eixos com baixo caimento orientados segundo a direção N30-60E.
A primeira fase deformacional $\left(D_{1}\right)$ deforma as estruturas primárias e gera a primeira foliação metamórfica $\left(S_{1}\right)$ mostrada no diagrama estrutural da figura 9B. O acamadamento sedimentar apresenta a mesma orientação da foliação principal (Fig. 9A). Esta foliação pode ser observada em campo como uma clivagem ardosiana e/ou uma xistosidade fina com espaçamento milimétrico definido pela orientação das micas. A presença localizada de uma lineação de estiramento (Fig. 9E) é indicativa de que esta fase ocorreu sob condições elevadas de deformação dúctil e desenvolveu texturas miloníticas com estiramento do quartzo e dos feldspatos (Fig. 6D). Os dados estruturais 

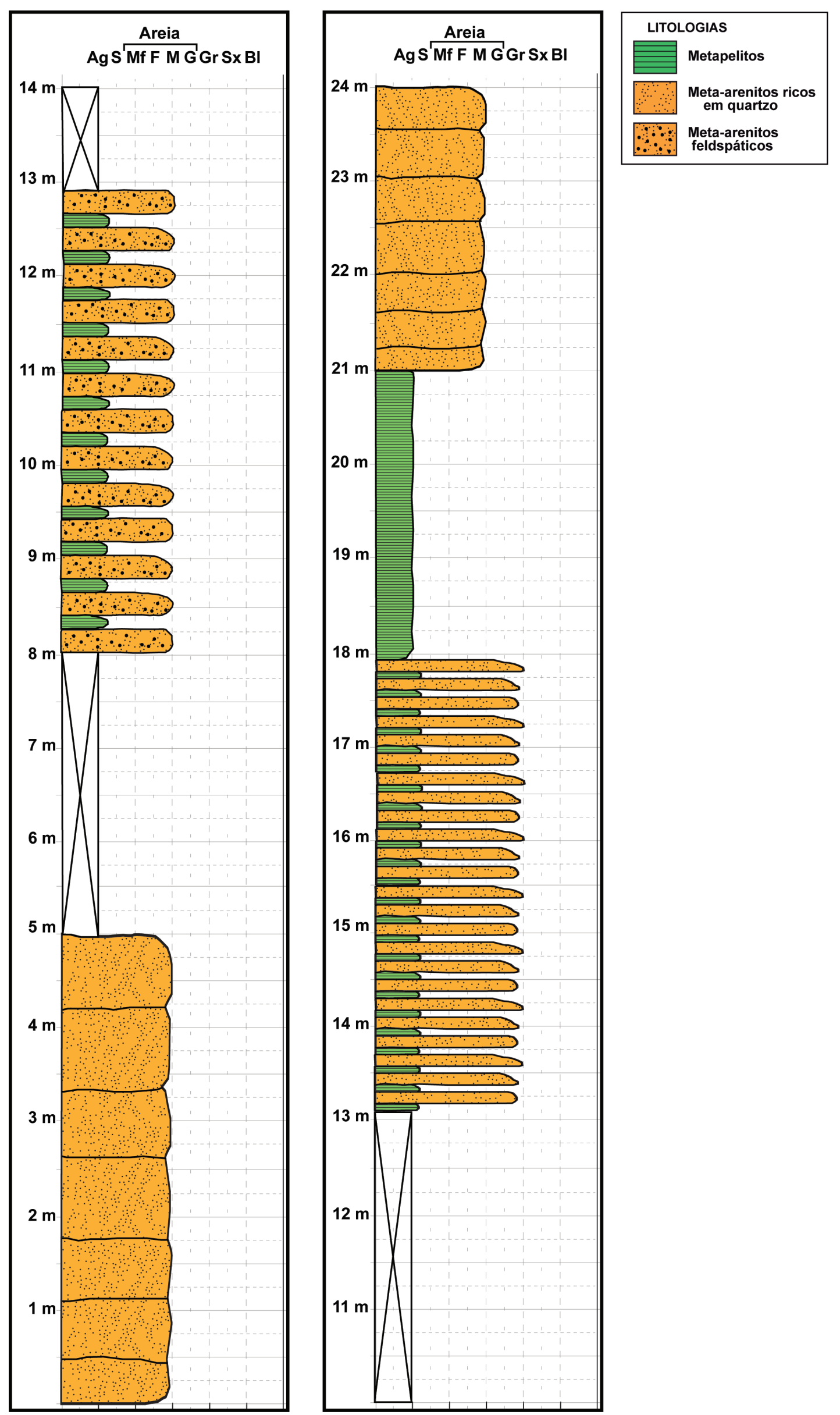

Figura 5. Perfis colunares levantado a partir dos pontos descritos. Figure 5. Columnar profiles raised from the points described. 

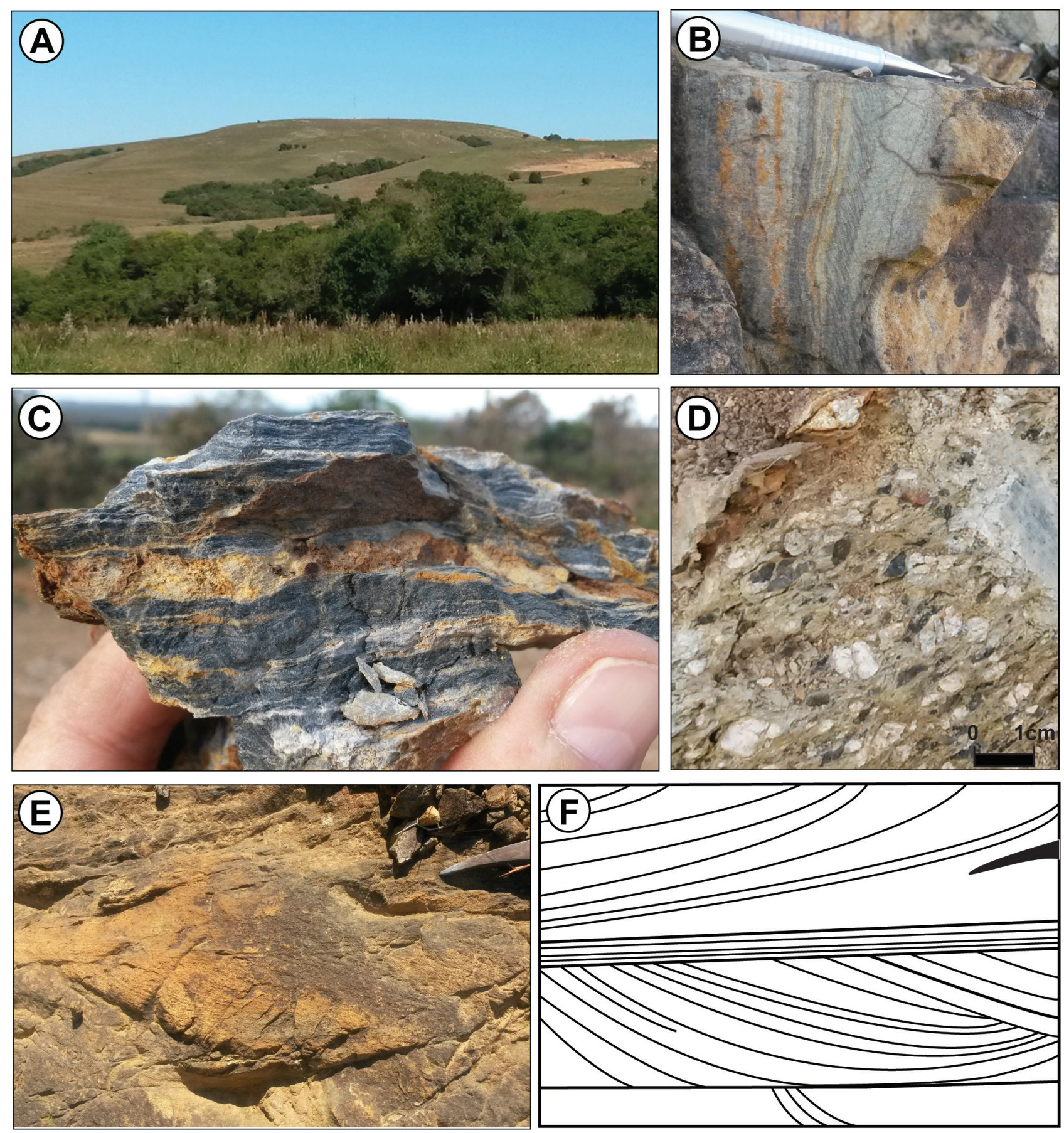

Figura 6. Feições macroscópicas de campo. A) Imagem ou Fotografia (ajustar em todos os casos) de campo Vista geral mostrando as cristas de quartzito que constituem a Coxilha do Batovi; B) Meta-arenito com estratificação cruzada de pequeno porte; C) Foto de uma formação ferrífera bandada metapelito; D) Foto de afloramento em planta exibindo a textura blastopsamítica em meta-arcóseo conglomerático, destacando porfiroclastos estirados de feldspato (branco) e quartzo (cinza) envoltos por uma matriz fina de cor bege rica em minerais micáceos e quartzo recristalizado; E) Metaarcóseo com estrutura cruzada acanalada; F) Interpretação das estruturas da fotografia anterior.

Figure 6. Macroscopics field features. A) Field photo General view showing the crests of quartzite that constitute the Coxilha do Batovi hill; B) Preserved small-size cross stratification in meta-sandstone; C) Photo of a band iron formationmetapelite; D) Photo of outcropping showing the blastopsamitic texture in conglomeratic meta-sandstone, highlighting stretched porphyroclasts of feldspar (white) and quartz (gray) wrapped in a fine matrix of beige color rich in micaceous minerals and recrystallized quartz; E) Meta-arkose with cross-stratification structure; F) Interpretation of the structures of the previous photograph 

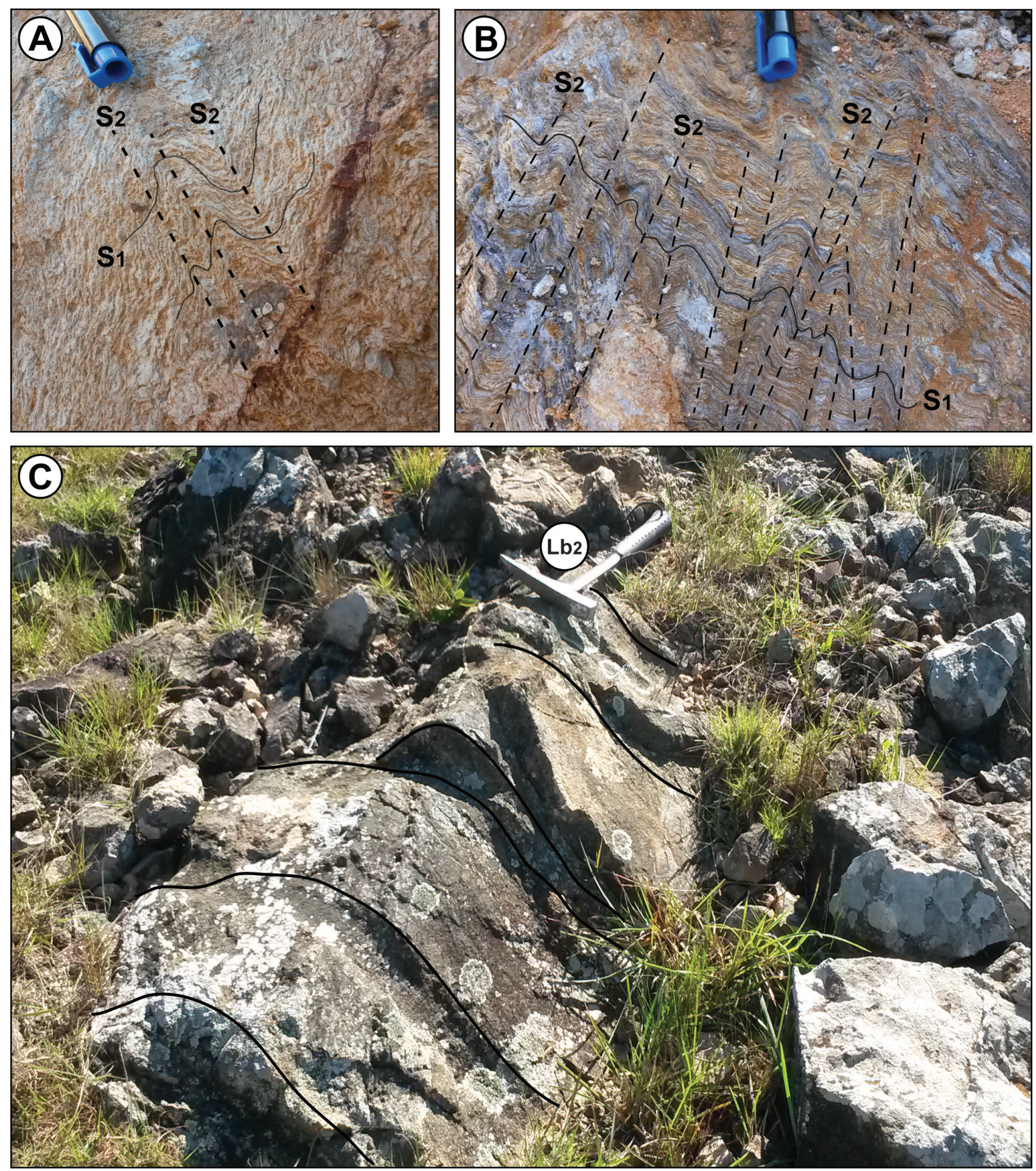

Figura 7. Estruturas tectônicas dos metassedimentos do Complexo Coxilha do Batovi. A) Meta-arenito com clivagem de crenulação $\left(S_{2}\right)$ e dobras $F_{2}$ geradas pelo dobramento da xistosidade $S_{1}$; B) Metaritmito com clivagem de crenulação $\left(S_{2}\right)$ e dobras $\mathrm{F}_{2} ; \mathrm{C}$ ) Dobra $\mathrm{F}_{2}$ em quartzito com eixo $\left(\mathrm{Lb}_{2}\right)$ mostrando baixo caimento para NW.

Figure 7. Tectonic structures of metasediments of the Coxilha do Batovi Complex. A) and B) Metarithmite with crenulation cleavage $\left(\mathrm{S}_{2}\right)$ and $\mathrm{F}_{2}$ folds generated by the folding of the schistosity $\mathrm{S}_{1} ; \mathrm{C}$ ) Fold $\mathrm{F}_{2}$ with axis $\left(\mathrm{Lb}_{2}\right)$ showing low rake for NW. 
apresentados no diagrama da figura 9B indicam que a atitude média da foliação $S_{1}$ é $N 58^{\circ} \mathrm{W}$, com mergulho médio de 67 graus para NE. A observação do mesmo diagrama mostra que a foliação $S_{1}$ apresenta uma ampla guirlanda de atitudes dos pólos da foliação, gerando um padrão geral de dobras assimétricas com eixos segundo a direção $\mathrm{N} 30-50^{\circ} \mathrm{W}$, como podemos observar na figura 9F.

A segunda fase deformacional $\left(D_{2}\right)$ é responsável pela estruturação final do complexo. As formas dômicas e alongadas na direção NW-SE, que compõem o Complexo Coxilha do Batovi, representam grandes antiformes com caimento de até $30^{\circ}$ para NW e SE. Apresenta marcante desenvolvimento de falhas e fraturas paralelas aos planos axiais das megadobras $\left(F_{2}\right)$. As dobras associadas a essa fase deformacional são representadas por antiformes e sinformes, onde localmente observa-se a transposição da foliação $S_{1}$ e formação de $S_{2}$ (Fig. 7A-B). Os dados estruturais apresentados no diagrama da figura $9 \mathrm{C}$ indicam que a atitude média da foliação $\mathrm{S}_{2}$ é $\mathrm{N} 80^{\circ} \mathrm{W}$, com mergulho médio de 75 a 80 graus para SW. As dobras $F_{2}$ apresentam eixos com caimentos entre 10 e 30 graus segundo a direção N30-60 W (Fig. 9C).

A fase de deformação $D_{3}$ está caracterizada pelo dobramento das foliações $S_{1}$ e $S_{2}$ gerando dobras $\mathrm{F}_{3}$ de formas abertas a suaves, simétricas a assimétricas, com o comprimento de onda variando de $20 \mathrm{~cm}$ a $10 \mathrm{~m}$ ou ainda maiores (Fig. 8). A superfície axial das dobras $F_{3}$ é definida por uma clivagem de fratura com direção principal $\mathrm{N} 45-50^{\circ} \mathrm{E}$ que corta perpendicularmente as estruturas anteriores. Os indicadores cinemáticos observados são dobras assimétricas que indicam o sentido do transporte tectônico verificado de noroeste para sudeste. De maneira geral, a direção e sentido da compressão não mudam ao longo dos regimes de empurrão e transcorrência, fato que sugere que esses regimes estão relacionados a um único evento tectônico. Os dados estruturais apresentados no diagrama da figura 9D indicam que a atitude média da foliação $\mathrm{S}_{3}$ é $\mathrm{N} 45^{\circ} \mathrm{E}$, com mergulho médio entre 70 e $80^{\circ}$ SE. A observação do mesmo diagrama mostra as dobras $\mathrm{F}_{3}$ assimétricas com caimentos dos eixos entre 20 e 70 graus segundo a direção N40-60 $\mathrm{E}$.
A relação de superposição entre as fases $D_{2}$ e $\mathrm{D}_{3}$ ocorrem em escala meso- e macroscópica produzindo um padrão de interferência do tipo domo e bacia.

\subsection{Análise petrográfica}

\subsubsection{Metapsamitos}

Os meta-arenitos possuem composição dominantemente quartzosa, com predomínio de quartzitos e ocorrência subordinada de meta-arcóseos. Apresentam uma clivagem ardosiana a xistosidade muito fina definida pela orientação de níveis submilimétricos a milimétricos e descontínuos de muscovita e clorita (Fig. 10B) e pela orientação preferencial dos porfiroclastos quartzo-feldspáticos. Essa característica é verificada nos termos menos ou mais deformados (Fig. 10A-B e Fig. 10C$D$, respectivamente). A principal textura é a blastopsamítica, caracterizada por porfiroclastos de quartzo e feldspato de tamanho areia média à grossa $(0,25-1 \mathrm{~mm})$, envoltos por uma matriz de composição quartzo-feldspática com arranjo granoblástico interlobado fino (Fig. 10C-D). Nos níveis micáceos apresenta textura lepidoblástica fina a média (Fig. 10B). Observamse ainda texturas diagenéticas parcialmente preservadas, tais como cutículas de argilominerais mecanicamente infiltrados (Fig 10B e 10F), crescimentos em grãos de quartzo engolfando lamelas de argilo-minerais (Fig. 10E), estilolitos, dissolução de grãos de quartzo por compactação mecânica, contatos suturados entre grãos (Fig. 10B) e cutículas de hematita marcando o contorno de grãos dissolvidos.

Os porfiroclastos compõem cerca de 30$35 \%$ da rocha para os termos menos afetados pela deformação e $20-25 \%$ para os mais afetados. São predominantemente de quartzo e, subordinadamente, de K-feldspato e plagioclásio, com formas equidimensionais, subangulosos a subarredondados, com esfericidade moderada. É notável que os porfiroclastos de quartzo geralmente apresentam extinção ondulante e feições de estiramento, formando quartzo ribbon, com cauda de recristalização (Fig. 10C e 10D), com exceção dos domínios afetados 

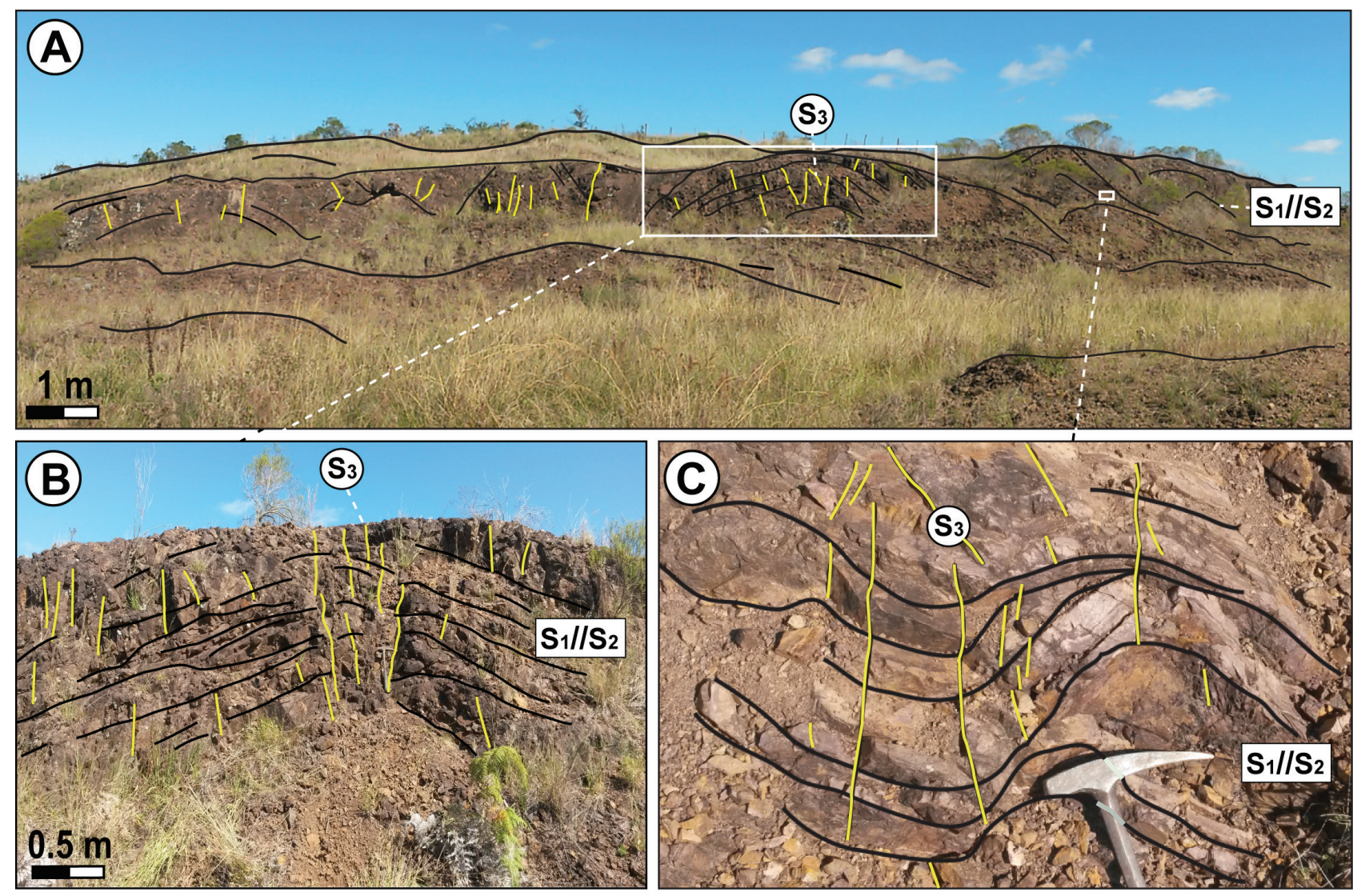

Figura 8. Afloramento de meta-arenito em pedreira de brita desativada. A) Vista geral. Os traços pretos destacam a foliação principal (S1//S2) enquanto os traços amarelos destacam as fraturas marcando as superfícies axiais das dobras $\mathrm{F}_{3}$; B) Detalhe mostrando a xistosidade $\mathrm{S}_{1} / / \mathrm{S}_{2}$ dobrada pela fase de deformação $\mathrm{D}_{3}$, produzindo a clivagem de fratura $\mathrm{S}_{3}$ (em amarelo); $\mathrm{C}$ ) Detalhe de uma dobra $\mathrm{F}_{3}$ assimétrica de pequeno porte.

Figure 8. Meta-sandstone outcrop in stone gravel disable quarry. A) General view. The black lines highlight the main foliation while the yellow lines define the axial surfaces of the $F_{3}$ folds; B) Detail showing the schistosity $\left(S_{1}+S_{2}\right)$ folded by the $D_{3}$ deformation phase, producing the $S_{3}$ fracture (yellow); C) Detail of a small asymmetric $F_{3}$ fold.

por deformação de muito baixa intensidade. A partir dessa característica, é possível inferir que a extinção ondulante nos grãos de quartzo é resultante da fase sin-deformacional. Os porfiroclastos de microclínio (Fig. 10E) ainda têm preservadas maclas, mesmo com a intensa substituição para albita (Fig. 10B) dos feldspatos. A observação da figura 13C permite identificar que, acompanhando o acamamento sedimentar, podem ocorrer bandas finas e contínuas ricas em minerais opacos, zircão e alanita, que juntamente com os minerais acessórios, titanita, epidoto (Fig. 10F) e fluorita, perfazem 3-10\% do arcabouço. Os litoclastos de arenitos são compostos dominantemente por quartzo e feldspatos de tamanho areia média a grossa $(0,25-1 \mathrm{~mm})$. Compõem por volta de $30 \%$ da rocha, alcançando até $74 \%$ (Fig. 10A e Fig. 10C, respectivamente). É interessante observar que com a progressão da deformação esses litoclastos, que inicialmente apresentam seus contatos bem definidos, vão sendo estirados, engolfando parcialmente os porfiroclastos, formando uma pseudo-matriz e tendo suas bordas recristalizadas (Fig. 10E-F). Nos termos quartzíticos, onde a deformação é intensa, esses litoclastos apresentamse esmagados e recristalizados a ponto de formarem a matriz que envolve os porfiroclastos de quartzo estirados, caracterizando a textura blastopsamítica (Fig. 10D). Essa observação realça o papel da dissolução por pressão de grãos primários fornecendo sílica para o processo de recristalização.

\subsubsection{Metapelitos}

Os metapelitos apresentam xistosidade definida pela orientação de muscovita e clorita, contém ainda teores baixos de quartzo e minerais opacos como porfiroclastos e veios de quartzo 


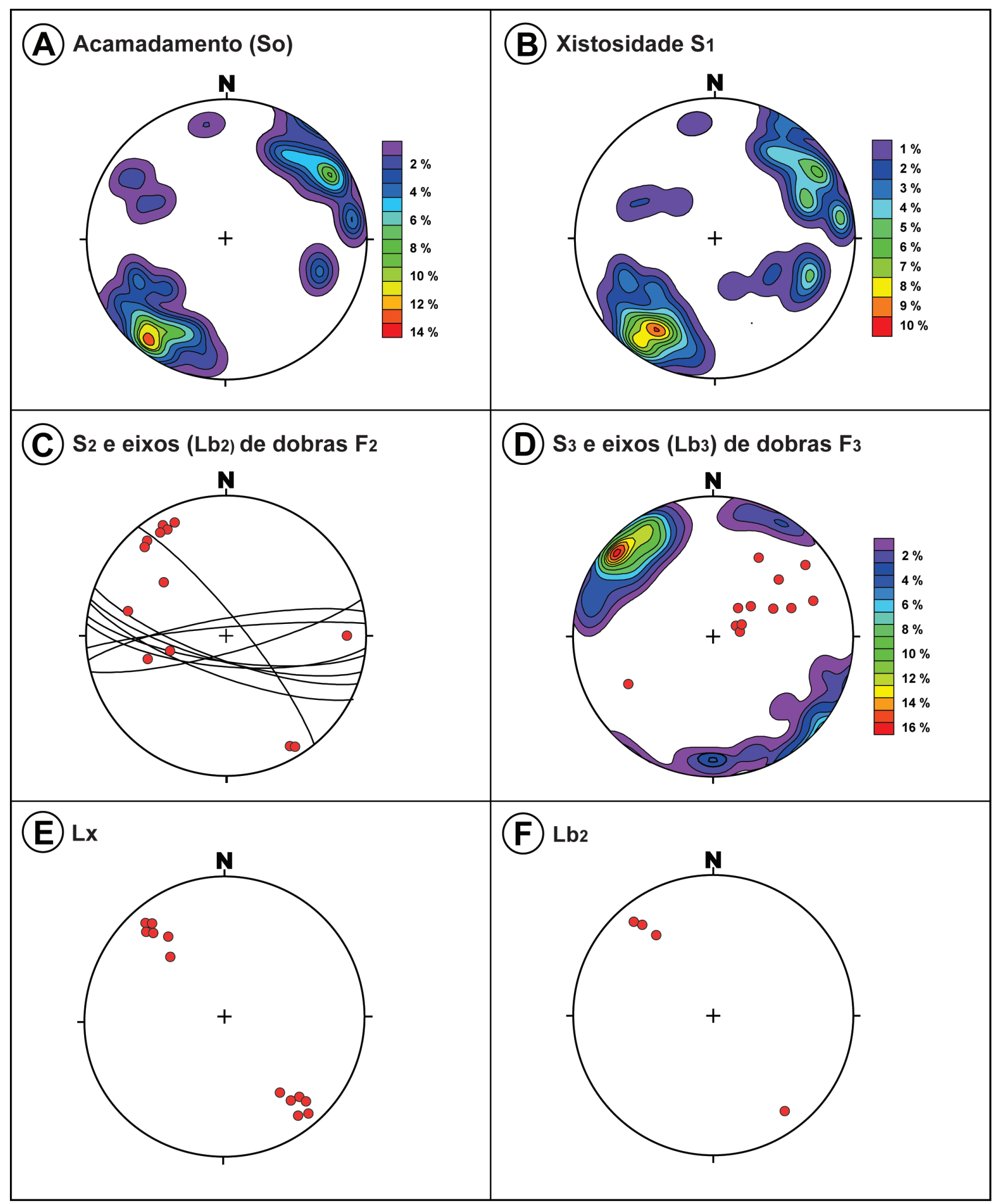

Figura 9. Estruturas planares e lineares identificadas nos metassedimentos do CCB representadas em rede equiárea de Schmitt (hemisfério inferior). A) Diagrama de contorno para a distribuição de pólos dos planos de acamadamento sedimentar $\left(S_{0}\right)(n=61)$; B) Diagrama de contorno para a distribuição de pólos dos planos das foliações metamórficas $S_{1}$ e $\left.S_{2}(n=72) ; C\right)$ Planos de superfície axiais $\left(S_{2}\right)$ e orientação dos eixos das dobras $F_{2}$ (círculos vermelhos); D) Diagrama de contorno para a distribuição de pólos dos planos das fraturas $\mathrm{S}_{3}$ e orientação dos eixos das dobras $\mathrm{F}_{3}$ (círculos vermelhos) ( $n=83)$; E) Orientação das lineações de estiramento $(L x)(N=11) ; F)$ Disposição dos eixos das dobras $F_{2}(n=4)$. Figure 9. Planar and linear structures identified in the CBC metasediments represented in Schmit equatorial network (lower hemisphere). A) Contour diagram for the distribution of poles of the sedimentary bedding planes $\left(S_{0}\right)(n=61)$; B) Contour diagram for the distribution of poles of the metamorphic foliation planes $S_{1}$ and $S_{2}(n=72)$; $\left.C\right)$ Axial surface planes $\left(S_{2}\right)$ and orientation of the axes of the $F_{2}$ folds (red circles); D) Contour diagram for the pole distribution of the planes of fractures $S_{3}$ and orientation of the axes of the $F_{3}$ folds (red circles) $(n=83)$; E) Orientation of stretch lineations $(L x)(n=11) ; F)$ Disposition of the $F_{2}$ axis $(n=4)$. 


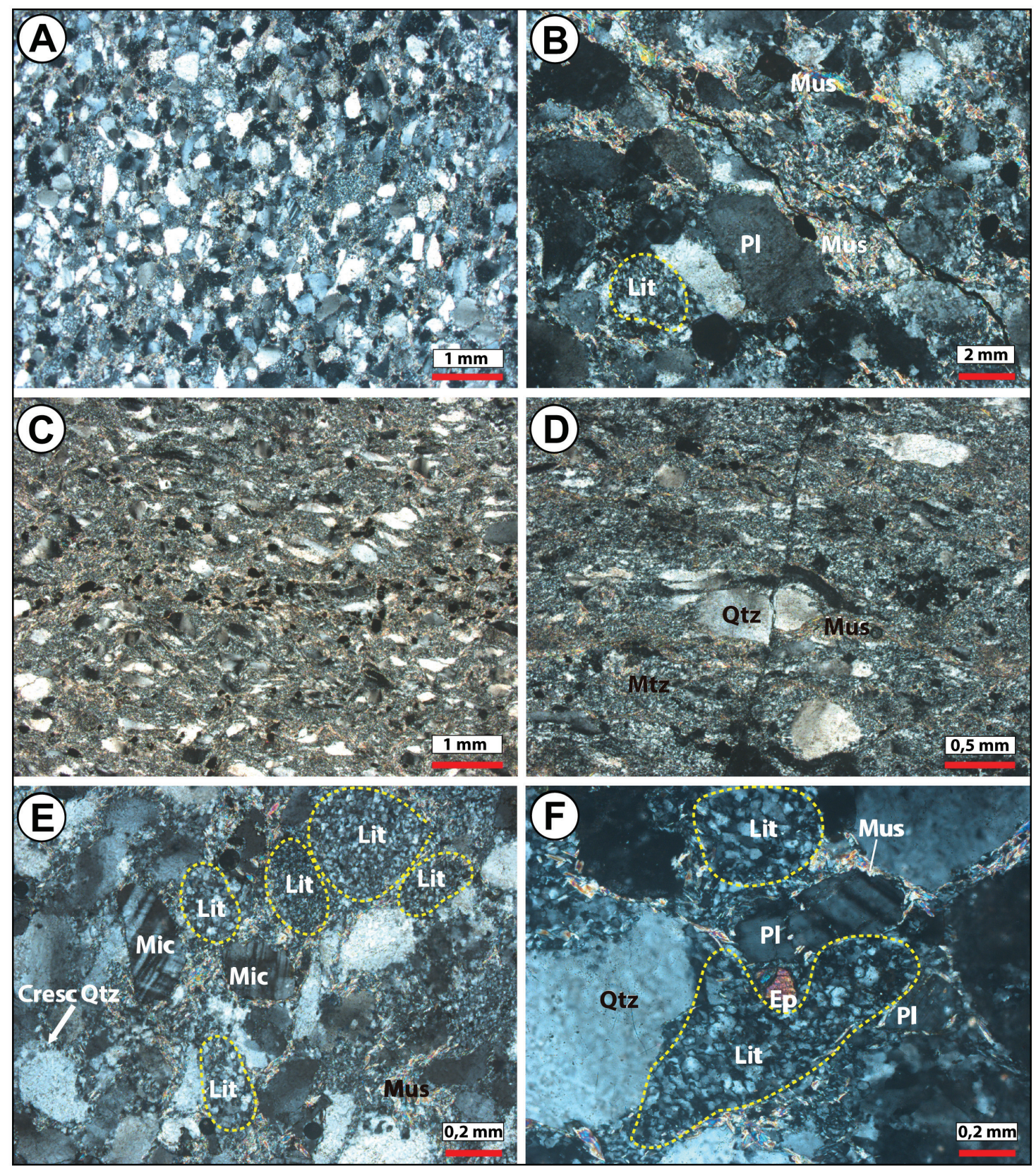

Figura 10. Feições microscópicas primárias das unidades do CCB. A) Meta-arenito com textura blastopsamítica caracterizada por clastos subangulosos de quartzo e feldspatos; B) Detalhe da amostra anterior destacando litoclastos de arenitos quartzitos finos (Lit) e clastos de plagioclásio (PI) envoltos por agregados de muscovita metamórfica (Mus); C) Meta-arenito protomilonítico com textura blastopsamítica ressaltando os porfiroclastos de quartzo estirados; D) Detalhe da amostra anterior destacando os clastos estirados de quartzo e muscovita (Mus) tipo fish , envoltos em um matriz quartzo-feldspática com textura granoblástica equigranular fina (Mtz). Observar na porção central da imagem, uma microfalha associada a um plano de fratura da S3; E) Detalhe de meta-arenito com porfiroclastos de microclínio (Mic) e quartzo (Qz), e litoclastos subarredondados de arenitos (Lit) envoltos por uma matriz granoblástica equigranular fina rica em quartzo e muscovita. Em destaque franja de crescimento de quartzo (seta); F) Detalhe da amostra anterior ressaltando os porfiroclastos de quartzo (Qzt) e plagioclásio (PI) e os litoclastos de arenitos, envoltos por uma matriz granoblástica fina composta por quartzo, feldspato, epidoto (Ep) e muscovita.

Figure 10. Primary microscopic features of the CBC units. A) Meta-sandstone with blastopsamitic texture characterized by clasts of quartz and feldspars; B) Detail of the previous sample highlighting lithoclasts of fine arenites (Lit) and plagioclase (Pl); C) Protomylonitic meta-sandstone with blastopsamitic texture emphasizing the stretched quartz porphyroclasts; D) Detail of the previous sample highlighting the stretched clasts of quartz and fish-type muscovite, wrapped in a quartz-feldspatic matrix with a fine equigranular granoblastic texture; E) Detail of meta-sandstone with microcline $(\mathrm{Mc})$ and quartz $(\mathrm{Qz})$ porphyroclasts, and arenite (Lit) lithoclasts enveloped by a matrix with granoblastic equigranular fine texture rich in quartz and muscovite; F) Detail of the previous sample highlighting the porphyroclasts of quartz and plagioclase and arenites lithoclasts (Lit) surrounded by a fine granoblastic matrix composed of quartz, feldspar, epidote and muscovite. 
aproveitando os planos gerados pela foliação $S_{2}$ A principal textura é lepidoblástica fina à média $\left(0,1\right.$ a 0,4 mm). A xistosidade $S_{1}$ está transposta e observam-se microdobras $F_{2}$ isoclinais com e sem raiz indicando a formação da clivagem de crenulação $S_{2}$ (Fig. 11A-B). Também são registradas dobras $F_{3}$ do tipo "kink" e "chevron" afetando a xistosidade $\mathrm{S}_{1}$ e $\mathrm{S}_{2}$. Essas dobras são consequência da terceira fase de deformação, ocorrendo transposição local das foliações $S_{1} /$ $S_{2}$ gerando uma clivagem de crenulação $S_{3}$ (Fig. 11C). A xistosidade possui espaçamento milimétrico, controlado pela orientação das micas e alternância dos níveis micáceos com níveis finos a base de quartzo microcristalino e clorita. Em partes menos deformadas, preservam o micro-acamadamento gradacional e apresentam uma matriz de minerais argilosos, matéria orgânica e quartzo microcristalino sem extinção ondulante. Apresenta ainda clastos de zircão, turmalina e opacos. Nos termos mais deformados a mineralogia original encontra-se recristalizada, e dessa maneira, tem-se quartzo microcristalino, muscovita, clorita e grafita, podendo ocorrer também calcita micrita na matriz e veios de quartzo fibroso nos planos axiais das microdobras.

\subsubsection{Metabasito}

A amostra MS-029A apresenta uma xistosidade muito fina defınida pela orientação de clorita, muscovita e actinolita. As texturas principais são lepidoblástica e nematoblástica fina (Fig. 11D). Observa-se ainda um bandamento submilimétrico defınido pela alternância de níveis félsicos, compostos por quartzo microcristalino e microcristais euédricos de plagioclásio com forma prismática alongada, substituídos localmente por sericita. Os níveis máficos são compostos por agregados de lamelas de clorita, com teores variáveis de actinolita, na forma de cristais aciculares $(0,3$ a 0,7 mm) e localmente por cristais subidioblásticos de magnetita $(0,1$ a 0,4 mm) (Fig. 11D).

\subsubsection{Mármores}

Os mármores apresentam em geral textura granoblástica fina à média. O mármore dolomítico silicoso descrito por Schmitt (1995) apresenta textura granoblástica equigranular média à fina e mineralogia composta por dolomita, calcita, quartzo, talco e grafita, contendo porfiroclastos de quartzo, K-feldspato, plagioclásio, zircão, granada, apatita e opacos. Os xistos calcisilicáticos apresentam xistosidade fina definida pela orientação de muscovita, contendo teores variáveis de quartzo, carbonatos, minerais opacos.

O grafita mármore calcítico tem cor escura devido à recristalização da matéria orgânica para grafita, e estão cortados por diversas gerações de veios de espessuras milimétricas de calcita branca com textura granoblástica grossa. Apresenta ainda calcita microcristalina, quartzo detrítico, muscovita, teores variáveis de grafita e sulfetos (pirita e arsenopirita). Os veios exibem zoneamento composicional com calcita espática nas bordas e quartzo recristalizado no centro.

\subsubsection{Formação Ferrífera Bandada}

Foram descritas duas litofacies para esta unidade (Schmitt, 1995). As formações ferríferas ricas em pirita, apresentando 70\% de matriz composta por grunerita, ferroactinolita (anfibólios) e clorita. Os anfibólios marcam a lineação mineral desta formação, e os pórfıros de quartzo e pirita apresentam discreto estiramento.

As formações ferríferas ricas em magnetita apresentam uma matriz composta por grunerita, estilpnomelano e quartzo microcristalino, contendo porfiroclastos de quartzo e opacos estirados.

\section{Discussão dos resultados}

\subsection{Variação composicional}

Os dados decampo eos perfis sedimentares levantados demonstraram que o CCB está representado por uma espessa intercalação de metassedimentos, com predomínio de metaarenitos quartzosos com relação a metaarcóseos e metapelitos, ocorrendo camadas subordinadas de metacalcáreos grafitosos e mármores dolomíticos silicosos, rochas 


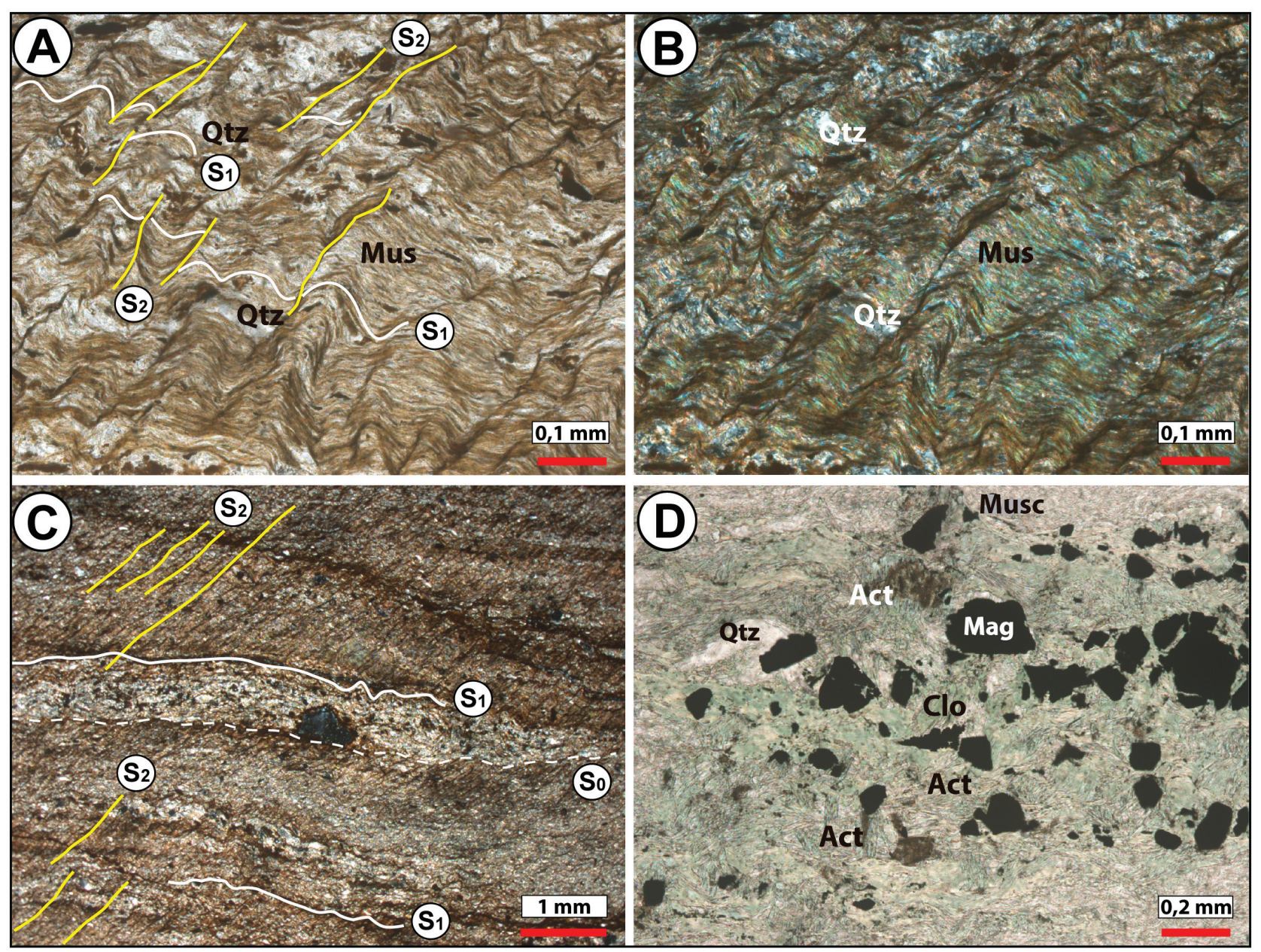

Figura 11. Feições microscópicas tectônicas das unidades do CCB. A) Clivagem de crenulação $S_{2}$ em metapelitos; B) Mesma imagem anterior com polarizadores cruzados; C) Acamadamento primário $\left(\mathrm{S}_{0}\right)$ caracterizado pela alternância de camadas contínuas de areia grossa e areia fina. A foliação $S_{1}$ está paralela ao acamadamento, e a foliação $S_{2}$ corta as estruturas anteriores em ângulo alto; D) Magnetita-muscovita-actinolita-clorita xisto com estrutura acamadada sugerindo um protólito tufáceo. Legenda: Qtz=quartzo, Mus=muscovita, Act=actinolita, Ser=sericita, Mag=magnetita, Clo=clorita.

Figure 11. Microscopic tectonic features of CBC units. A) Crenulation cleavage $S_{2}$ in metapelites; B) Same previous image with crossed polarizers; $C$ ) Primary layering $\left(S_{0}\right)$ characterized by the alternation of continuous layers of coarse and fine sand. The foliation $S_{1}$ is parallel to the bedding and the foliation $S_{2}$ cuts the anterior structures at high angle; D) Magnetite-muscovite-actinolite-chlorite schist with layered structure suggesting a tufaceous protolith. Legend: Qtz=quartz, Mus=muscovite, Act=actinolite, Ser=sericite, Mag=magnetite, $C l o=$ clorite.

metavulcânicas, formações ferríferas bandadas, talco xisto e metagranitos. Estas unidades sugerem que o complexo está composto por associações petrotectônicas de ambientes distintos, dispostas lado a lado por ação de uma longa e intensa tectônica deformadora.

As análises petrográficas indicaram que os metapsamitos, principal unidade do complexo, variam entre quartzo-arenitos e arcóseos. As texturas blastopsamíticas mostraram que os porfiroclastos de quartzo e de feldspatos, incluindo Kf e plagioclásio, são subangulosos a subarredondados, com esfericidade baixa à média, estão envoltos por proporções variadas de matriz quartzo-feldspática fina.
A variação composicional, incluindo o predomínio de metapsamitos com altos teores de quartzo e feldspatos, associados a mármores calcíticos e dolomiticos, pode sugerir que o paleoambiente que originou o complexo foi de um mar raso, em uma provável bacia intracratônica ou de margem passiva. As feições texturais, como a pouca maturidade e esfericidade, sugerem um transporte rápido e um ciclo deposicional de curta duração. A ocorrência comum de estruturas primárias preservadas, como estratificação plano-paralela, cruzada acanalada e cruzada de baixo ângulo corrobora com o tipo de ambiente proposto. Apesar das transformações impostas pela deformação e 
pelo metamorfismo, as feições composicionais e texturais observadas podem sugerir que a sucessão sedimentar descrita esteve relacionada a uma deposição em ambientes deltaicos e/ou pró-deltaicos.

\subsection{Evolução estrutural}

Foram identificadas três fases de deformação, com geração de duas foliações metamórficas $\left(S_{1}\right.$ e $\left.S_{2}\right)$ e uma clivagem de fratura pervasiva $\left(\mathrm{S}_{3}\right)$. As duas primeiras fases ocorreram emambientedúctil esob condições metamórficas de baixo grau, entre a fácies Xistos Verdes, indicada nos meta-arenitos pela paragênese clorita+muscovita+quartzo+K-feldspato. $\mathrm{Na}$ terceira fase de deformação, as feições principais são estruturas de caráter rúptildúctil, localmente apresentando recristalização de muscovita, sugerindo condições de muito baixa temperatura. Em levantamento estrutural desenvolvido por Schmitt (1995), a formação das foliações metamórficas $S_{1}$ e $S_{2}$ foi interpretada como produto de um regime tectônico de empurrão, atuando sobre rochas sedimentares intercaladas com rochas vulcânicas. Salientou ainda, que estas fases apresentam caráter dúctil evidenciado por dobras isoclinais associadas a falhas de empurrão e pela concordância dos indicadores cinemáticos, que indicam um movimento de noroeste para sudeste.

A segunda fase deformacional $\left(D_{2}\right)$ é responsável pela estruturação final do complexo. Nessa fase, o regime tectônico ativo é o de transcorrência. As formas dômicas e alongadas na direção NW-SE, que compõem o complexo, dentre elas o Coxilha do Batovi, são grandes antiformes com caimento de até $30^{\circ}$ para NW e SE. As dobras são representadas por antiformes e sinformes, onde localmente observa-se a transposição da foliação $S_{1}$ e formação de $S_{2}$. A foliação $S_{2}$ desenvolve em zonas de alta deformação feições miloníticas observadas comumentenos meta-arenitos. Os protomilonitos e milonitos observados apresentam uma lineação de estiramento de baixo rake, sugerindo que o seu desenvolvimento está relacionado a um regime de transcorrência e associado com a instalação da Zona de Cisalhamento Ibaré.
Dados geocronológicos de U-Pb em zircão sugerem que o metamorfismo que afetou as unidades do Terreno São Gabriel ocorreu entre 710 e 700 Ma (Remus et al., 1999; Hartmann et al., 2007; Saalmann et al., 2010). Por outro lado, observa-se que a Zona de Cisalhamento Ibaré atuou como uma importante estrutura que controlou entre 630 e $570 \mathrm{Ma}$, o posicionamento de suítes graníticas neoproterozoicas no Terreno Taquarembó (Camozzato et al., 2016).

A terceira fase deformacional ocasiona o dobramento das foliações metamórficas $\mathrm{S}_{1}$ e $\mathrm{S}_{2} \mathrm{e}$ a formação de dobras $F_{3}$ abertas do tipo normal, com caimento segundo a direção NE. Estas dobras estão associadas com uma tectônica transcorrente mais jovem associada à instalação e deposição das unidades vulcano-sedimentares da Bacia do Camaquã.

\subsection{Tipo de bacia}

Os perfis estratigráficos levantados indicam uma sucessão sedimentar marcada por um espesso pacote de arenitos quartzosos e arcoseanos, sucedidos por uma intercalação rítmica de arenitos e pelitos, sobrepostos por outro pacote de arenitos. Os aspectos estruturais, texturais e composicionais observados, como estruturas cruzadas e acanaladas, seleção média e esfericidade baixa à média dos clastos de areia, intercalação com metacalcáreos e pelitos, permitem supor uma sedimentação de baixa energia em uma bacia intracratônica ou de margem passiva.

A paleogeografia regional apresenta ao sul da Zona de Cisalhamento Ibaré os orto- e paragnaisses paleoproterozoicos do Complexo Granulítico Santa Maria Chico. As rochas metavulcanossedimentares dos complexos Coxilha do Batovi e Marmeleiro estão dispostas como corpos alongados ao longo desta zona de cisalhamento. Esta constatação levou alguns pesquisadores (Philipp et al., 2013, 2016a) a correlacionar estes complexos como uma única unidade original. Ao norte deste limite tectônico, são descritas diversas associações vulcânicas e plutônicas relacionadas a arcos magmáticos e complexos ofiolíticos de idades neoproterozoicas, pertencentes ao Terreno São Gabriel (Chemale 
Jr. 2000; Hartmann et al., 2007; Saalmann et al., 2010; Philipp et al., 2016a). A relação entre estes complexos metavulcanossedimentares e as unidades do Complexo Granulítico Santa Maria Chico situado ao sul, permite aventar a hipótese de que os metassedimentos possam representar a margem passiva do oceano Charrua (Philipp et al., 2016a). Desta forma, a pouca maturidade dos metapsamitos do Complexo Coxilha do Batovi, indicam para esta bacia sedimentar uma área fonte proximal, cuja deposição final ocorrera a partir da formação de deltas no encontro com o oceano Charrua.

As características paleogeográficas, associada com as variações composicionais e estruturais e ao grau metamórfico, sugerem que o Complexo Coxilha do Batovi pode ser correlacionado com o Complexo Arroio Marmeleiro situado mais ao sudeste, ao longo da Zona de Cisalhamento Ibaré.

\section{Conclusões}

As rochas do Complexo Coxilha do Batovi representam uma sucessão de sedimentos de ambiente marinho transicional, incluindo a plataforma continental ou fundo marinho (metapelitos e grafita mármore calcítico). Estas rochas estão intercaladas com rochas metavulcânicas (metabasaltos, espilitos, metavulcanoclásticas e formações ferríferas bandadas), recobertos por depósitos turbidíticos progradantes (metapsamitos calcíferos e arcoseanos, metapelitosemarmores dolomíticos) que são por sua vez, estão recobertos pelo espesso pacote arenoso de mar raso composto pelo metapsamitos quartzíticos. Esses sedimentos foram depositados provavelmente em ambientes do tipo deltas e/ou pró-deltas na margem do Terreno Taquarembó.

Estes metassedimentos progradantes podem estar caracterizando a margem passiva do Microcontinente ou Terreno Nico Perez com relação ao oceano Charrua, conforme Philipp et al. (2016a). A colisão continental entre os sistemas de arcos do terreno São Gabriel e o Terreno Taquarembó (Nico Perez) ocasionou a deformação e metamorfismo das unidades do complexo, gerando as foliações metamórficas
$\mathrm{S}_{1}$ e $\mathrm{S}_{2}$. O encurtamento e a deformação do CCB está associado à etapa final deste processo de colisão e vinculado a uma cinemática transcorrente responsável pela formação da Zona de Cisalhamento Ibaré. A colisão ocorrida no final do Neoproterozoico entre os crátons Rio de La Plata e Kalahari deforma as unidades do complexo e as estruturas anteriores gerando os dobramentos tardios com eixos de direção NESW associados à terceira fase de deformação regional.

Novos estudos de proveniência detrítica através de geocronologia e geologia isotópica pelos métodos $\mathrm{U}$-Pb e Lu-Hf em zircão permitirão avaliar esta hipótese de evolução tectônica.

\section{Referências}

Almeida, F.F.M., Hasui, Y., de Brito Neves, B.B. \& Fuck, R.A. 1981. Brazilian structural provinces: an introduction. Earth-Science Reviews, 17(12): $1-29$.

Arena, K.R., Hartmann, L.A. \& Lana, C. 2016. Evolution of Neoproterozoic ophiolites from the southern Brasiliano Orogen revealed by zircon $\mathrm{U}-\mathrm{Pb}-\mathrm{Hf}$ isotopes and geochemistry. Precambrian Research, 285: 299-314.

Babinski, M., Chemale, F., Hartmann, L.A., Van Schmus, W.R. \& da Silva, L.C. 1996. Juvenile accretion at 750-700 Ma in southern Brazil. Geology, 24(5): 439-442.

Bitencourt, M.F.A.S. 1983. Metamorfitos da região de Caçapava do Sul, RS - Geologia e relações com o grupo granítico. In: SIMPÓSITO SULBRASILEIRO DE GEOLOGIA, 1., 1983, Porto Alegre. Atas... Porto Alegre, SBG, v. 1, p. 37-49.

Bitencourt, M.F.A.S. \& Nardi, L.V.S. 2000. Tectonic setting and sources of magmatism related to the Southern Brazilian Shear Belt. Revista Brasileira de Geociências, 30(1): 184-187.

Camozzato, E., Philipp, R.P., Laux, J.H., Chemale Jr., F. \& Iglesias, C.M.F. 2016. O Batólito Torquato Severo e a colagem dos terrenos Taquarembó e São Gabriel. In: CONGRESSO BRASILEIRO DE GEOLOGIA, 46, 2016, Porto Alegre. Anais... Porto Alegre, SBG, v. 1.

Carraro, C.C., Gamermann, N., Eick, N.C., Bortoluzzi, C.A., Jost, H. \& Pinto, J.F. 1974. 
Mapa geológico do Estado do Rio Grande do Sul. Porto Alegre, Instituto de Geociências, Universidade Federal do Rio Grande do Sul, escala: 1:1.000.000.

Carvalho, P.F. 1932. Reconhecimento geológico no Estado do Rio Grande do Sul. Boletim do Serviço Geológico e Mineralógico, Ministério da Agricultura, 66: 1-72.

Chemale Jr., F. 1982. Geologia da Região de Palma, São Gabriel, Rio Grande do Sul. Porto Alegre, 136p. Dissertação de Mestrado, Programa de Pós-graduação em Geociências, Instituto de Geociências, Universidade Federal do Rio Grande do Sul.

Chemale Jr., F. 2000. Evolução Geológica do Escudo Sul-rio-grandense. In: Ianuzzi, R. \& Frantz, J.C. (Eds.). Geologia do Rio Grande do Sul. Porto Alegre, CIGO/UFRGS, p. 13-52.

Chemale, F., Philipp, R.P., Dussin, I.A., Formoso, M.L.L., Kawashita, K. \& Berttotti, A.L. 2011. Lu$\mathrm{Hf}$ and $\mathrm{U}-\mathrm{Pb}$ age determination of Capivarita Anorthosite in the Dom Feliciano Belt, Brazil. Precambrian Research, 186(1): 117-126.

Fernandes, L.A., Tommasi, A. \& Porcher, C.C. 1992. Deformation patterns in the southern Brazilian branch of the Dom Feliciano Belt: a reappraisal. Journal of South American Earth Science, 5(1): 77-96.

Fragoso-Cesar, A.R.S. 1980. O Cráton do Rio de La Plata e o Cinturão Dom Feliciano no Escudo Uruguaio-Sul Riograndense. In: CONGRESSO BRASILEIRO DE GEOLOGIA, 31, 1980, Camboriú. Anais... Camboriú, SBG, v. 5, 2879-2891.

Fragoso-Cesar, A.R.S. 1991. Tectônica de Placas no Ciclo Brasiliano: As Orogenias dos Cinturões Dom Feliciano e Ribeira no Rio Grande do Sul. São Paulo, 362p. Tese de Doutorado, Programa de Pós-graduação, Instituto de Geociências, Universidade de São Paulo.

Garcia, M.A.M., \& Hartmann, L.A. 1981. Petrologia do Complexo Palma- RS. Acta

Geológica Leopoldensia, 3(9): 51-119.

Goñi, J.C., Goso, H.J. \& Issler, R.S. 1962. Estratigrafia e geologia econômica do préCambriano e Eo-paleozoico uruguaio e sul-riograndense. Escola de Geologia, Universidade Federal do Rio Grande do Sul, Porto Alegre, v.3, p. 1-105.
Hartmann, L.A., Chemale Jr., F. \& Philipp, R.P. 2007. Evolução geotectônica do Rio Grande do Sul no Precambriano. In: lanuzzi, R. \& Frantz, J.C. (Eds.). 50 anos de Geologia. Porto Alegre, Editora Comunicação e Identidade, CIGO/UFRGS, p. 97-123.

Issler, R.S., Jost, H., Villwock, J.A., Pinto, J.F., Gammermann, N., Figueiredo Filho, P.M., Bortoluzzi, C.A., Carraro, C.C. \& Eick, N.C. 1972. Mapa Geológico do Grau de São Gabriel-RSBrasil. Porto Alegre, Instituto de Geociências, Universidade Federal do Rio Grande do Sul, escala 1:100.000.

Jost, H. \& Villwock, J.A. 1966. Contribuição a estratigrafia do Pré-Cambriano do Rio Grande do Sul. Notas e Estudos da Escola de Geologia, 1(1): 13-26.

Laux, J.H., Bongiolo, E.M., Junior, F.C. \& Santos, T. 2010a. U-Pb data from Ibaré Formation: a volcano-sedimentary sequence of São Gabriel Arc, Rio Grande do Sul-Brazil. In: SOUTH AMERICAN SYMPOSIUM ON ISOTOPE GEOLOGY, 7., 2010, Brasilia, Boletim de Resumos ..., p. 74-77.

Laux, J.H., Bongiolo, E.M., Chemale Jr, F. \& Santos, T.C. 2010b. U-Pb of Cerro Batovi Metamorphic Complex. First record of statherian rocks in the Rio Grande do Sul state-Brazil. In: SOUTH AMERICAN SYMPOSIUM ON ISOTOPE GEOLOGY, v. 7., 2010, Brasilia, Boletim de Resumos ..., p. 78-81.

Leinz, V. 1946. Ocorrências de calcário no Rio Grande do Sul e prospecção da jazida de "Vacacaí", no município de São Gabriel. Estudos Brasileiros de Geologia, 1: 1-46.

Naumann, M.P. 1985. O complexo volcanosedimentar-ultramáfico e granitoides da região Ibaré, RS. 7985. Porto Alegre, 162p. Dissertação de Mestrado, Programa de Pósgraduação em Geociências, Instituto de Geociências, Universidade Federal do Rio Grande do Sul.

Oyhantçabal, P., Siegesmund, S. \& Wemmer, K. 2011. The Rio de la Plata Craton, a review of units, boundaries, ages and isotopic signature. International Journal of Earth Sciences, 100: 201-220.

Philipp, R.P. \& Machado, R. 2005. The Late Neoproterozoic granitoid magmatism of the 
Pelotas Batholith, southern Brazil. Journal of South American Earth Sciences, 19: 461-478.

Philipp, R.P., Nardi, L.V.S. \& Bitencourt, M.F. 2000. O Batólito Pelotas no Rio Grande do Sul. In: Holz, M. \& De Ros, L.F. (Ed.). Geologia do Rio Grande do Sul. Porto Alegre, CIGO/UFRGS, p. 133-160.

Philipp R.P., Massone H.J. \& Campos R.S. 2013. Peraluminous leucogranites of Cordilheira Suite, record of Neoproterozoic collision and generation of Pelotas Batholith, Dom Feliciano Belt, southern Brazil. Journal of South American Earth Sciences, 43: 8-24.

Philipp, R.P., Pimentel, M.M. \& Chemale Jr., F. 2016a. Tectonic evolution of the Dom Feliciano Belt in southern Brazil based on geological relationships and $\mathrm{U}-\mathrm{Pb}$ geochronology. Brazilian Journal of Geology, 46(1): 83-104.

Philipp, R.P., Bom, F.M., Pimentel, M.M., Junges, S.L. \& Zvirtes, G. 2016b. Shrimp U-Pb age and ultra-high temperature conditions of the collisional metamorphism in the Várzea do Capivarita Complex: implications for the origin of Pelotas Batholith, Dom Feliciano Belt, southern Brazil. Journal of South American Earth Sciences, 66: 196-207.

Rapela, C.W., Fanning, C.M., Casquet, C., Pankhurst, R.J., Spaletti, L., Poiré, D. \& Baldo, E.G. 2011. The Rio de La Plata craton and the adjoining Pan-African-Brasiliano terranes: their origins and incorporation into southwest Gondwana. Gondwana Research, 20: 673-690.

Remus, M.V.D. 1990. Geologia e geoquímica do Complexo Cambaizinho, São Gabriel-RS. Porto Alegre, 267p. Dissertação de Mestrado, Programa de Pós-graduação em Geociências, Instituto de Geociências, Universidade Federal do Rio Grande do Sul.

Remus, M.V.D., Hartmann, L.A., McNaughton, N.J. \& Fletcher, I.R. 1999. SHRIMP U/Pb zircon ages of volcanism from the São Gabriel Block, southern Brazil. In: SIMPÓSIO SOBRE VULCANISMO E AMBIENTES ASSOCIADOS, 1., 1999, Gramado. Boletim de Resumos... Porto Alegre, SBG, v. 1, p. 83.

Saalmann, K.; Hartmann, L.A. \& Remus, M.V.D. 2005. Tectonic evolution of two contrasting schist belts in southernmost Brazil: A plate tectonic model for the Brasiliano orogeny. International Geology Review, 47: 1234-1259.

Saalmann, K., Gerdes, A., Lahaye, Y., Hartmann, L.A., Remus, M.V.D. \& Läufer, A. 2010. Multiple accretion at the eastern margin of the Rio de la Plata craton: the prolonged Brasiliano orogeny in southernmost Brazil. International Journal of Earth Sciences, 100: 355-378.

Schmitt, R.S., Guerra-Sommer, M., Medeiros, R.A. \& Lemos, V.B. 1993. Laminitos criptomicrobiais em Sequência carbonática do Pré-Cambriano no Rio Grande do Sul, Brasil. In: CONGRESSO BRASILEIRO DE PALEONTOLOGIA, 13., SIMPÓSIO PALEONTOLÓGICO DO CONE SUL, 1., São Leopoldo, 1993. Boletim de Resumos Expandidos... São Leopoldo, SBG., v. 1, p. 205.

Schmitt, R.S. 1995. Evolução tectonometamórfica do complexo metavulcanosedimentar Coxilha do Batovi, São Gabriel, RS. Porto Alegre, 159p. Dissertação de Mestrado, Programa de Pós-Graduação em Geociências, Instituto de Geociências, Universidade Federal do Rio Grande do Sul.

Silva, L.C., McNaughton, N.J., Armstrong, R., Hartmann, L.A. \& Fletcher, I.R. 2005. The Neoproterozoic Mantiqueira Province and its African connections, a zircon-based $\mathrm{U}-\mathrm{Pb}$ geochronologic subdivision of the Brasiliano/ Pan-African systems of orogens. Precambrian Research, 136: 203-240.

Soliani Jr., E. 1986. Os dados geocronológicos do Escudo Sul-rio-grandense e suas implicações de ordem geotectônica. São Paulo, 425p. Tese de Doutorado, Programa de Pós-Graduação em Geociências, Instituto de Geociências, Universidade de São Paulo.

Szubert, E.C. \& Presotto, C.A. 1974. Geologia e reserva dos calcários metamórficos do Rio Grande do Sul. In: CONGRESSO BRASILEIRO DE GEOLOGIA, 28., 1974, Porto Alegre. Anais... Porto Alegre, SBG., v.6, p. 103-114.

UFRGS. Universidade Federal do Rio Grande do Sul. 1986. Mapeamento Geológico - Projeto Suspiro. Porto Alegre. Trabalho de Graduação do Curso de Geologia, Instituto de Geociências, Universidade Federal do Rio Grande do Sul.

Vedana, L.A., Philipp, R.P. \& Sommer, C.A. 2017. Post-collisional basalts of the Acampamento Velho Formation, Camaquã Basin, São Gabriel 
Terrane, southernmost Brazil. Brazilian Journal of Geology, 47(3): 467-489.

Wildner, W. 1990. Caracterização Geológica e Geoquímica das Sequências Ultramáfica e Vulcanossedimentares da Região da Bossoroca. Porto Alegre, 215p. Dissertação de Mestrado, Programa de Pós-graduação e Geociências, Instituto de Geociências, Universidade Federal do Rio Grande do Sul.

Zarpelon, P.R. 1986. Geologia Estrutural, Estratigrafia e Petrologia de uma parte do Greenstone Belt Cerrito do Ouro, Município de São Sepé, RS. Porto Alegre, 203p. Dissertação de Mestrado, Programa de Pós-graduação em Geociências, Instituto de Geociências, Universidade Federal do Rio Grande do Sul. 